\title{
Thiolation and Carboxylation of Glutathione Synergistically Enhance Its Lead Detoxification Capabilities
}

Luca Sauser, ${ }^{[a] \ddagger}$ Tagwa A. Mohammed, ${ }^{[a] \ddagger}$ Tadeáš Kalvoda, ${ }^{[b]}$ Sheng-Jan Feng, ${ }^{[a]}$ Bernhard Spingler, ${ }^{[a]}$ Lubomír Rulíšek, ${ }^{[b]}$ and Michal S. Shoshan*[a]

[a] Department of Chemistry

University of Zurich

Winterthurerstrasse 190, 8057 Zurich, Switzerland

E-mail: michal.shoshan@chem.uzh.ch

[b] Institute of Organic Chemistry and Biochemistry

Czech Academy of Sciences

Flemingovo náměstí 2, 16610 Praha 6, Czech Republic

¥These authors contributed equally to this work.

\section{Table of Contents}

1 General materials and methods $\quad 2$

2 Synthesis of SPPS building blocks 4

3 General protocols for SPPS 11

4 Analytical data of the peptides $\quad 12$

$5 \quad$ In vitro studies $\quad 14$

6 Complexes characterization $\quad 19$

$7 \quad$ Quantum chemical calculations 28

8 References $\quad 32$ 


\section{General materials and methods}

Materials and reagents were of the highest grade available, purchased from ABCR, Sigma Aldrich, $\mathrm{TCl}$, or Fluorochem, and used without further purification. Amino acids were purchased from Merck, Bachem, Novabiochem, Senn, or ABCR and used as received.

Water used for peptide preparation and purification was nanopure ("Milli-Q") prepared by a Barnstead GenPure system (ThermoFisher Scientific).

Solid-phase peptide synthesis was performed on 200-400 mesh 2-Chlorotrityl chloride Polystyrene resin from $A B C R$.

${ }^{1} \mathrm{H}$ and ${ }^{13} \mathrm{C}$ NMR spectra were recorded on a Bruker AVII-400 (400 MHz) or AV-NEO-600 (600 $\mathrm{MHz})$, chemical shifts are reported in ppm using the solvent residual peak as reference $\left(\mathrm{D}_{2} \mathrm{O} 4.79\right.$ ppm for ${ }^{1} \mathrm{H}, \mathrm{CDCl}_{3} 7.26 \mathrm{ppm}$ for ${ }^{1} \mathrm{H}$, and $77.16 \mathrm{ppm}$ for ${ }^{13} \mathrm{C}$ ). Assignment of the signals in the onedimensional ${ }^{1} \mathrm{H}$ NMR spectra was confirmed when needed by two-dimensional NMR spectroscopy (COSY, TOCSY, NOESY, HSQC, HMBC).

High-resolution mass spectrometry measurements were performed on a timsTOF Pro TIMSQTOF-MS instrument (Bruker Daltonics $\mathrm{GmbH}$ ).

Cell culture Human colon adenocarcinoma cells (HT-29) were purchased from the American Type Culture Collection (ATCC). The cells were grown in a humidified $5 \% \mathrm{CO}_{2}$ atmosphere at $37^{\circ} \mathrm{C}$ using Roswell Park Memorial Institute medium (RPMI-1640) with 25 mM HEPES, supplemented with 1\% L-glutamine, $1 \%$ penicillin/streptomycin, and 10\% fetal calf serum (FCS) superior (standardized). Culture medium RPMI-1640-HEPES (with L-glutamine), penicillin $(10.000 \mathrm{U} / \mathrm{mL})$, and streptomycin $(10 \mathrm{mg} / \mathrm{mL}$ ) were purchased from Sigma Aldrich, Invitrogen, or BioConcept. Trypsin-EDTA (0.02\%) in $\mathrm{Ca}(\mathrm{II})$ and $\mathrm{Mg}$ (II) deficient phosphate-buffered saline (PBS) (1:250) was purchased from Amimed. FCS superior was purchased from Oxoid AG and Biochrom AG. Crystal violet (CV) was purchased from Sigma Aldrich. CV assays were monitored on a Hidex Sense microplate reader.

UV-Vis spectrophotometer selectivity measurements were performed on a Lambda 850 UV-Vis spectrophotometer (PerkinElmer) with an ultra-micro Suprasil quartz cuvette (Hellma) with a chamber volume of $100 \mu \mathrm{L}$ and a path-length of $10 \mathrm{~mm}$. Wavelength scans were performed at 25 ${ }^{\circ} \mathrm{C}$ from 200 to $400 \mathrm{~nm}$, with a $40 \mathrm{~nm} \mathrm{~min}{ }^{-1}$ scan speed. 
Isothermal titration calorimetry (ITC) experiments were performed on a VP-ITC MicroCalorimeter (MicroCal, Malvern) at $25^{\circ} \mathrm{C}$. The ITC data were analyzed using the Origin software and fitted by one or two sets of sites binding models.

Inductively coupled plasma mass spectrometer (ICP-MS) experiments were performed with an Agilent QQQ 8800 Triple quad ICP-MS spectrometer, equipped with a standard $\mathrm{x}$-lens setting, nickel cones, and a "micro-mist" quartz nebulizer. The feed was $0.1 \mathrm{ml} / \mathrm{min}$. The RF power 1550 W. Tune settings were based on the Agilent General Purpose method and only slightly modified by an autotune procedure using an Agilent $1 \mathrm{ppb}$ tuning solution containing $\mathrm{Li}, \mathrm{Y}, \mathrm{Ce}$, and $\mathrm{TI}$. Values are reported as the average of triplicates. Elements were measured in a "helium-mode". 


\section{Synthesis of SPPS building blocks}

\subsection{Synthesis of Fmoc-Asp(tBu, STmob)-OH (Fmoc-X-OH) ${ }^{1}$}<smiles>O=C(O)CCCCCOC(=O)C[C@H](NC(=O)OCc1ccccc1)C(=O)O</smiles>

S1<smiles>CCCOC(=O)C[C@H](NC(=O)OCc1ccccc1)C(=O)OC</smiles>

S2

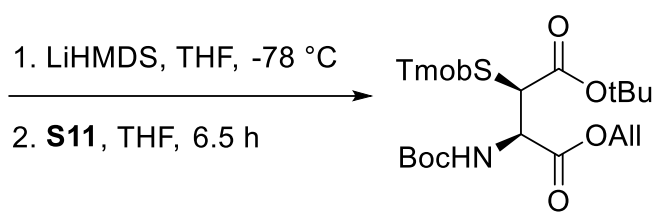

S3

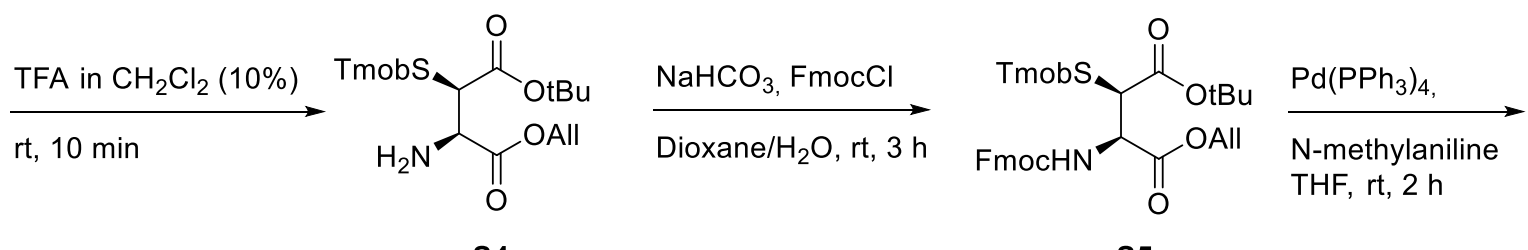

S4
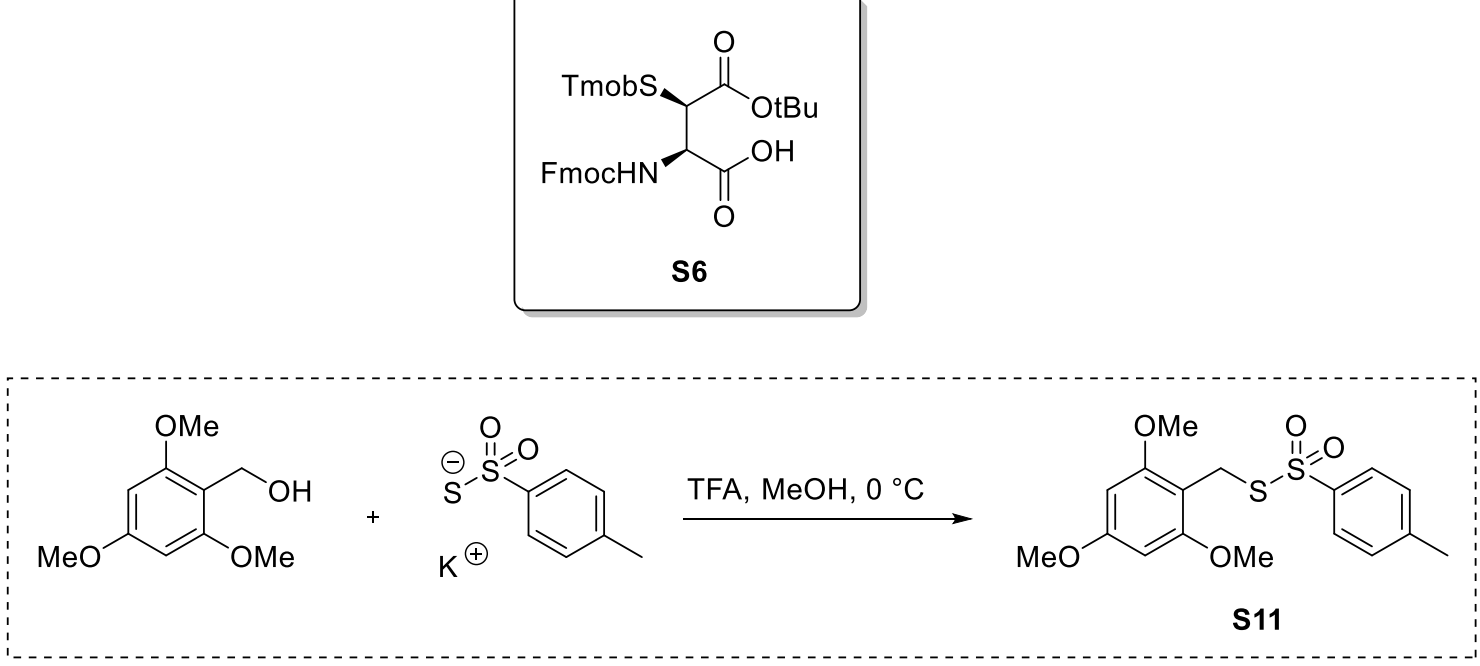

\subsubsection{S-(2,4,6-trimethoxybenzyl)-4-methylbenzenesulfonothioate (S11) ${ }^{2}$}

$4.0 \mathrm{~g}$ of 2,4,6-trimethoxybenzylalcohol (20 mmol, 1 equiv.) and $4.6 \mathrm{~g}$ of potassium $p$-toluenethiosulfonate (20 mmol, 1 equiv.) were dissolved in $100 \mathrm{~mL} \mathrm{CH}{ }_{3} \mathrm{OH}$. The mixture was cooled down to $0{ }^{\circ} \mathrm{C}$, and TFA (1.9 mL, $24 \mathrm{mmol}, 1.2$ equiv.) was added. The reaction was stirred for $20 \mathrm{~min}$. After filtration, the residue was dissolved in EtOAc for recrystallization. The desired product was obtained as white crystals ( $4.7 \mathrm{~g}, 12.7 \mathrm{mmol}, 64 \%)$.

${ }^{1} \mathrm{H}$ NMR (400 MHz, CDCl $) \delta(\mathrm{ppm}) 7.85(\mathrm{~d}, J=8.6 \mathrm{~Hz}, 2 \mathrm{H}), 7.32(\mathrm{~d}, J=8.6 \mathrm{~Hz}, 2 \mathrm{H}), 6.01(\mathrm{~s}, 2 \mathrm{H})$, $4.29(\mathrm{~s}, 2 \mathrm{H}), 3.77(\mathrm{~s}, 3 \mathrm{H}), 3.69(\mathrm{~s}, 6 \mathrm{H}), 2.45(\mathrm{~s}, 3 \mathrm{H})$ 


\subsubsection{Boc-Asp(tBu)-OAll (S2) ${ }^{2}$}

S1 (2.0 g, $6.9 \mathrm{mmol}, 1$ equiv.) was dissolved in $21 \mathrm{~mL}$ DMF. To a round-bottom flask, $0.7 \mathrm{~mL}$ of allyl bromide ( $8.2 \mathrm{mmol}, 1.2$ equiv.) and $1.6 \mathrm{~mL}$ of Hünig's base (9.0 mmol, 1.3 equiv.) were added. The reaction was stirred for $19 \mathrm{~h}$ at $\mathrm{rt}$. The solvent was removed under reduced pressure. The crude was filtered through a short column (Hexane:EtOAc 4:1). The solvent was removed under reduced pressure, and the desired product was obtained as a colorless oil ( $1.5 \mathrm{~g}, 4.6 \mathrm{mmol}$, $66 \%)$.

${ }^{1} \mathrm{H}$ NMR $\left(400 \mathrm{MHz}, \mathrm{CDCl}_{3}\right) \delta(\mathrm{ppm}) 5.82(\mathrm{~m}, 1 \mathrm{H}), 5.46(\mathrm{~d}, J=8.7 \mathrm{~Hz}, 1 \mathrm{H}), 5.25(\mathrm{dd}, J=17.4,1.4 \mathrm{~Hz}$, 1H), $5.15(\mathrm{dd}, J=10.4,0.9 \mathrm{~Hz}, 1 \mathrm{H}), 4.56(\mathrm{~m}, 2 \mathrm{H}), 4.47(\mathrm{~m}, 1 \mathrm{H}), 2.90(\mathrm{dd}, J=16.8,4.9 \mathrm{~Hz}, 1 \mathrm{H}), 2.73$ (dd, J = 16.8, 4.7 Hz, 1H), $1.45(\mathrm{~s}, 9 \mathrm{H}), 1.44(\mathrm{~s}, 9 \mathrm{H})$

\subsection{3 (2R, 3R)-Boc-Asp(tBu, STmob)-OAll (S3) ${ }^{2}$}

S2 (2.2 g, $6.6 \mathrm{mmol}, 1$ equiv.) was dissolved in $65 \mathrm{~mL}$ dry THF in a dry round bottom flask. The solution was cooled down to $-78{ }^{\circ} \mathrm{C}$, and $14.7 \mathrm{~mL}$ of LiHMDS (1 $\mathrm{M}$ in THF, 14.7 mmol, 2.2 equiv.) was added dropwise for $30 \mathrm{~min}$, after which it was stirred for additional $30 \mathrm{~min}$. S11 (3.2 g, 8.8 mmol, 1.3 equiv.) was dissolved in $390 \mathrm{~mL}$ of dry THF and cooled to $-78^{\circ} \mathrm{C}$. The cold solution was added dropwise over $90 \mathrm{~min}$, after which the reaction was stirred for another $4 \mathrm{~h}$. The reaction was quenched with $200 \mathrm{~mL}$ saturated $\mathrm{NH}_{4} \mathrm{Cl}$. The organic solvent was then removed under reduced pressure, and the remaining mixture was extracted three times with $100 \mathrm{~mL}$ of EtOAc. The organic phase was washed with brine, dried with $\mathrm{Na}_{2} \mathrm{SO}_{4}$, and filtered. The solvent was removed under reduced pressure. The crude mixture $\left(90 \%\right.$ conversion according to ${ }^{1} \mathrm{H}$ NMR, obtaining only one diastereomer) was purified by column liquid chromatography on silica gel with Hexane:EtOAc (6:1). Starting material was recovered with an rf of 0.3 , and the desired product was eluted with an rf of $0.2(2.4 \mathrm{~g}, 4.4 \mathrm{mmol}, 66 \%)$.

${ }^{1} \mathrm{H}$ NMR (400 MHz, CDCl 3$) \delta(\mathrm{ppm}) 6.11(\mathrm{~s}, 2 \mathrm{H}), 5.88(\mathrm{~m}, 1 \mathrm{H}), 5.71(\mathrm{br} \mathrm{d}, J=10.1 \mathrm{~Hz}, 1 \mathrm{H}), 5.32(\mathrm{dq}$, $J=17.2,1.4 \mathrm{~Hz}, 1 \mathrm{H}), 5.22(\mathrm{dd}, \mathrm{J}=10.4,1.0 \mathrm{~Hz}, 1 \mathrm{H}), 4.74(\mathrm{dd}, \mathrm{J}=10.1,4.6 \mathrm{~Hz}, 1 \mathrm{H}), 4.65(\mathrm{~m}, 1 \mathrm{H})$, $4.58(\mathrm{~m}, 1 \mathrm{H}), 4.00(\mathrm{~d}, J=12.0 \mathrm{~Hz}, 1 \mathrm{H}), 3.99(\mathrm{~d}, J=4.2 \mathrm{~Hz}, 1 \mathrm{H}), 3.91(\mathrm{~d}, J=12.4 \mathrm{~Hz}, 1 \mathrm{H}), 3.80(\mathrm{~s}$, $6 \mathrm{H}), 3.81(\mathrm{~s}, 3 \mathrm{H}), 1.45(\mathrm{~s}, 9 \mathrm{H}), 1.43(\mathrm{~s}, 9 \mathrm{H})$ 


\subsubsection{H-Asp(tBu, STmob)-OAll (S4)}

S3 (5.2 g, $9.5 \mathrm{mmol}$ ) was dissolved in $520 \mathrm{~mL}$ of TFA (10\%) in $\mathrm{CH}_{2} \mathrm{Cl}_{2}$, and the reaction was stirred for $10 \mathrm{~min}$. The reaction was then immediately neutralized with $540 \mathrm{~mL}$ of saturated $\mathrm{NaHCO}_{3}$. The product was extracted with $\mathrm{CH}_{2} \mathrm{Cl}_{2}(\times 3)$, washed with brine, dried with $\mathrm{Na}_{2} \mathrm{SO}_{4}$, and the solvent was removed by reduced pressure. S4 was used for the next step without further purification.

\subsubsection{Fmoc-Asp(tBu, STmob)-OAll (S5)}

Crude S4 (4.2 g, 9.5 mmol, 1 equiv.) was dissolved in $5.2 \mathrm{~mL}$ dioxane. $\mathrm{NaHCO}_{3}$ (2.3 g, 27.3 mmol, 2.5 equiv.) in $20.8 \mathrm{~mL}$ of $\mathrm{H}_{2} \mathrm{O}$ and $5.2 \mathrm{~mL}$ dioxane and $\mathrm{Fmoc}-\mathrm{Cl}(3.2 \mathrm{~g}, 13.1 \mathrm{mmol}, 1.2$ equiv.) in $5.2 \mathrm{~mL}$ dioxane were added to the $\mathbf{S 4}$ solution. The reaction was stirred for $3 \mathrm{~h}$ at $\mathrm{rt}$, after which the solvent was removed under reduced pressure. The product was extracted with EtOAc (x3), washed with brine, dried with $\mathrm{Na}_{2} \mathrm{SO}_{4}$, and filtered. The solvent was removed under reduced pressure. S5 was purified by column liquid chromatography on silica gel with Hexane:EtOAc (4:1) to pure EtOAc. The product was obtained as a yellow solid (1.9 $\mathrm{g}, 2.9 \mathrm{mmol}, 31 \%)$.

${ }^{1} \mathbf{H}$ NMR (400 MHz, $\left.\mathrm{CDCl}_{3}\right) \delta(\mathrm{ppm}) 7.75(\mathrm{~m}, 2 \mathrm{H}), 7.61(\mathrm{~m}, 2 \mathrm{H}), 7.39(\mathrm{~m}, 2 \mathrm{H}), 7.28(\mathrm{~m}, 2 \mathrm{H}), 6.10(\mathrm{~s}$, 2H), $5.88(\mathrm{~m}, 1 \mathrm{H}), 5.32(\mathrm{dd}, J=17.3,1.4 \mathrm{~Hz}, 1 \mathrm{H}), 5.23(\mathrm{dd}, J=10.4,1.2 \mathrm{~Hz}, 1 \mathrm{H}), 4.86(\mathrm{dd}, J=10.0$, $4.5 \mathrm{~Hz}, 1 \mathrm{H}), 4.64(\mathrm{~m}, 2 \mathrm{H}), 4.43-4.20(\mathrm{~m}, 3 \mathrm{H}), 4.06(\mathrm{~d}, J=4.5 \mathrm{~Hz}, 1 \mathrm{H}), 4.02(\mathrm{~d}, J=12.4 \mathrm{~Hz}, 1 \mathrm{H})$, $3.94(\mathrm{~d}, J=12.4 \mathrm{~Hz}, 1 \mathrm{H}), 3.80(\mathrm{~s}, 6 \mathrm{H}), 3.79(\mathrm{~s}, 3 \mathrm{H}), 1.49(\mathrm{~s}, 9 \mathrm{H})$

${ }^{13} \mathrm{C}$ NMR (101 MHz, CDCl 3$) \delta$ (ppm) 171.0, 169.9, 160.6, 159.0, 156.5, 144.0, 141.3, 141.2, 131.5, 127.6, 127.6, 127.1, 127.1, 125.4, 124.7, 120.1, 119.9, 118.7, 106.9, 90.6, 82.5, 67.4, 66.2, 55.7, $55.6,55.3,48.9,47.1,27.9$

HRMS (ESI) $m / z$ : calculated for $\mathrm{C}_{36} \mathrm{H}_{41} \mathrm{NO}_{9} \mathrm{SNa}^{+}(\mathrm{M}+\mathrm{Na})^{+} 686.23942$; found: 686.23917

\subsubsection{Fmoc-Asp(tBu, STmob)-OH (S6)}

S5 (3.4 g, $5.2 \mathrm{mmol}$, 1 equiv.) was dissolved in $35 \mathrm{~mL}$ of THF, and $\mathrm{N}$-methylaniline (1.1 mL, 10.4 mmol, 2 equiv.) and $\mathrm{Pd}\left(\mathrm{PPh}_{3}\right)_{4}(300 \mathrm{mg}, 0.3 \mathrm{mmol}, 0.05$ equiv.) were added. The reaction was stirred for $2 \mathrm{~h}$ at $\mathrm{rt}$. The solvent was removed under reduced pressure, and the crude product was purified by column liquid chromatography with Hexane:EtOAc (3:1). S6 was then eluted with 
$1 \% \mathrm{AcOH}$ in EtOAc. The organic phase was washed with $\mathrm{H}_{2} \mathrm{O}\left(x_{3}\right)$, dried over $\mathrm{Na}_{2} \mathrm{SO}_{4}$, and removed under reduced pressure, to obtain the desired product as an orange solid ( $2.9 \mathrm{~g}, 4.6 \mathrm{mmol}, 89 \%)$. ${ }^{1} \mathrm{H}$ NMR (400 MHz, $\left.\mathrm{CDCl}_{3}\right) \delta(\mathrm{ppm}) 7.75(\mathrm{~m}, 2 \mathrm{H}), 7.70-7.43(\mathrm{~m}, 2 \mathrm{H}), 7.41(\mathrm{~m}, 2 \mathrm{H}), 7.32(\mathrm{~m}, 2 \mathrm{H})$, $6.12(\mathrm{~s}, 2 \mathrm{H}), 4.84(\mathrm{dd}, J=8.7,3.8 \mathrm{~Hz}, 1 \mathrm{H}), 4.38(\mathrm{~m}, 2 \mathrm{H}), 4.25(\mathrm{t}, J=7.1 \mathrm{~Hz}, 1 \mathrm{H}), 4.07$ (d, J = $3.8 \mathrm{~Hz}$, 1H), $4.02(\mathrm{~d}, J=12.7 \mathrm{~Hz}, 1 \mathrm{H}), 3.97(\mathrm{~d}, J=12.6 \mathrm{~Hz}, 1 \mathrm{H}), 3.81(\mathrm{~s}, 6 \mathrm{H}), 3.77(\mathrm{~s}, 3 \mathrm{H}), 1.52(\mathrm{~s}, 9 \mathrm{H})$

${ }^{13} \mathrm{C}$ NMR (101 MHz, CDCl $) \delta$ (ppm) 160.7, 159.0, 156.3, 143.8, 143.8, 141.3, 141.3, 132.2, 132.1, 128.6, 128.5, 127.8, 127.7, 127.1, 125.3, 120.0, 106.7, 90.6, 67.5, 55.7, 55.3, 55.1, 48.3, 47.1, 27.9 HRMS (ESI) $\mathrm{m} / \mathrm{z}$ : calculated for $\mathrm{C}_{33} \mathrm{H}_{36} \mathrm{O}_{9} \mathrm{NS}^{-}$(M-H)- 622.21163; found: 622.21194 
2.2 Synthesis of Boc-Glu(OH, SDMB)-OtBu (Boc-Z-OtBu $)^{3}$<smiles>CCCCOC(=O)[C@H](CCC(=O)O)NC(=O)OCc1ccccc1</smiles>

s7

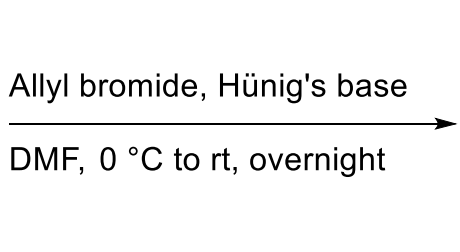

DMF, $0{ }^{\circ} \mathrm{C}$ to rt, overnight<smiles>CCCCOC(=O)CCC(N[C@@H](C)C(C)(C)C)C(=O)OCCC</smiles>

S8
1. LiHMDS, THF, $-78^{\circ} \mathrm{C}$

2. S22, THF

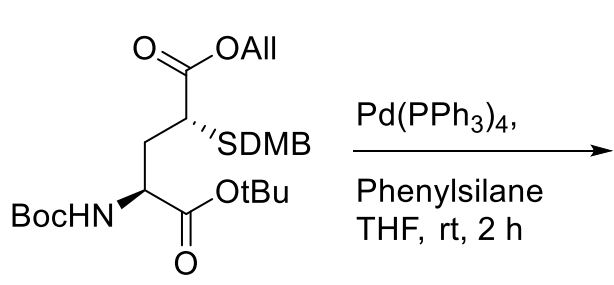

S9
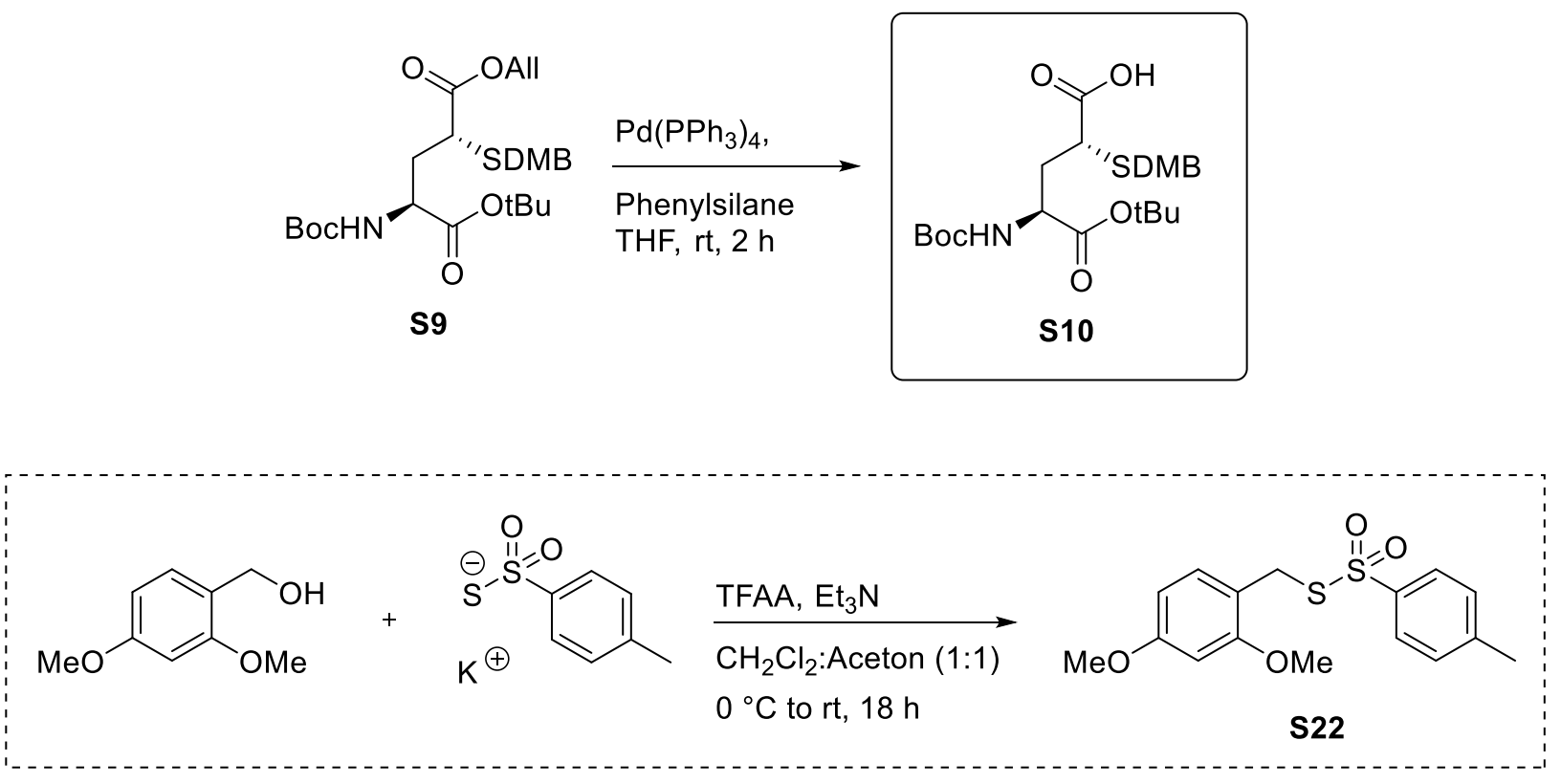

2.2.1 S-(2,4-dimethoxybenzyl)-4-methylbenzenesulfonothioate (S22)

$3.0 \mathrm{~g}$ of 2,4-dimethoxybenzyl alcohol (17.8 mmol, 1 equiv.) were dissolved in $\mathrm{CH}_{2} \mathrm{Cl}_{2}(30 \mathrm{~mL}$ ) and cooled down to $0^{\circ} \mathrm{C} .3 .2 \mathrm{~mL}$ of triethylamine (23.2 mmol, 1.3 equiv.) and $2.9 \mathrm{~mL}$ of trifluoroacetic anhydride ( $21.4 \mathrm{mmol}, 1.2$ equiv.) were added slowly to the solution. The mixture was then stirred for $20 \mathrm{~min}$ before adding $4.1 \mathrm{~g}$ of potassium $p$-toluene-thiosulfonate ( $17.8 \mathrm{mmol}, 1$ equiv.) in acetone $(30 \mathrm{~mL})$. The reaction was allowed to reach $\mathrm{rt}$ and was stirred for $18 \mathrm{~h}$. The solvent was removed under reduced pressure and extracted with EtOAc (x3). After removing the solvent, the solid residue was recrystallized with Hexane:EtOAc (2:3) to yield the desired product as white crystals (2.8 g, $8.4 \mathrm{mmol}, 47 \%)$.

${ }^{1} \mathrm{H}$ NMR $\left(400 \mathrm{MHz} \mathrm{CDCl}_{3}\right) \delta(\mathrm{ppm}) 7.78(\mathrm{dt}, J=8.4,1.8 \mathrm{~Hz}, 2 \mathrm{H}), 7.29(\mathrm{~d}, J=8.0 \mathrm{~Hz}, 2 \mathrm{H}), 7.01(\mathrm{~d}, J$ $=8.1 \mathrm{~Hz}, 1 \mathrm{H}), 6.35-6.31(\mathrm{~m}, 2 \mathrm{H}), 4.20(\mathrm{~s}, 2 \mathrm{H}), 3.77(\mathrm{~s}, 3 \mathrm{H}), 3.71(\mathrm{~s}, 3 \mathrm{H}), 2.44(\mathrm{~s}, 3 \mathrm{H})$ 


\subsubsection{Boc-Glu(OAll)-OtBu (S8)}

$5.0 \mathrm{~g}$ of $\mathbf{S 7}$ (16.5 mmol, 1 equiv.) were dissolved in $50 \mathrm{~mL} \mathrm{DMF}$ and cooled to $0{ }^{\circ} \mathrm{C} .3 .0 \mathrm{~mL}$ of allyl bromide (34.6 mmol, 2.1 equiv.) and $6.0 \mathrm{~mL}$ of Hünig's base (34.6 mmol, 2.1 equiv.) were added at $0{ }^{\circ} \mathrm{C}$, and the reaction was stirred for $19 \mathrm{~h}$ at $\mathrm{rt} .100 \mathrm{~mL}$ of $\mathrm{H}_{2} \mathrm{O}$ were added, and the reaction mixture was extracted with EtOAc $(x 3)$. The combined organic layers were washed with $\mathrm{H}_{2} \mathrm{O}(x 5)$ and brine. The organic phase was dried over $\mathrm{Na}_{2} \mathrm{SO}_{4}$, and the solvent was removed under reduced pressure. The crude product was purified by column liquid chromatography on silica gel with Hexane:EtOAc (9:1). The desired product was obtained as colorless crystals $(5.1 \mathrm{~g}, 14.8 \mathrm{mmol}$, $90 \%)$.

${ }^{1} \mathrm{H}$ NMR (400 MHz, $\left.\mathrm{CDCl}_{3}\right) \delta(\mathrm{ppm}) 5.96-5.86(\mathrm{~m}, 1 \mathrm{H}), 5.31(\mathrm{dq}, J=17.3,1.4 \mathrm{~Hz}, 1 \mathrm{H}), 5.23(\mathrm{dq}, J$ $=10.4,1.1 \mathrm{~Hz}, 1 \mathrm{H}), 5.07(\mathrm{~d}, J=7.3 \mathrm{~Hz}, 1 \mathrm{H}), 4.58(\mathrm{~d}, J=5.7 \mathrm{~Hz}, 2 \mathrm{H}), 4.21(\mathrm{q}, J=5.0 \mathrm{~Hz}, 1 \mathrm{H}), 2.50-$ $2.34(\mathrm{~m}, 2 \mathrm{H}), 2.21-2.12(\mathrm{~m}, 1 \mathrm{H}), 1.96-1.87(\mathrm{~m}, 1 \mathrm{H}), 1.46(\mathrm{~s}, 9 \mathrm{H}), 1.44(\mathrm{~s}, 9 \mathrm{H})$

${ }^{13} \mathrm{C}$ NMR (101 MHz, CDCl $) \delta$ (ppm) 172.7, 171.5, 155.5, 132.2, 118.5, 82.3, 79.9, 65.4, 53.5, 30.4, $28.5,28.2,28.1$

HRMS (ESI) $m / z$ : calculated for $\mathrm{C}_{17} \mathrm{H}_{30} \mathrm{NO}_{6}{ }^{+}(\mathrm{M}+\mathrm{H})^{+} 344.20676$; found: 344.20679

\subsubsection{Boc-Glu(OAll, SDMB)-OtBu (S9)}

$500 \mathrm{mg}$ of $\mathbf{S} 8$ (1.45 mmol, 1 equiv.) were dissolved in $20 \mathrm{~mL}$ dry THF in a dry round bottom flask. The solution was cooled down to $-78^{\circ} \mathrm{C}$, and $3.2 \mathrm{~mL}$ of LiHMDS (1 M in THF, $3.2 \mathrm{mmol}$, 2.22 equiv.) were added dropwise over $10 \mathrm{~min}$, after which it was stirred for $1 \mathrm{~h}$. S22 (550 mg, $1.63 \mathrm{mmol}$, 1.12 equiv.) was dissolved in $4 \mathrm{~mL}$ of dry THF and cooled down to $-78^{\circ} \mathrm{C}$. The cold solution was then added dropwise over $10 \mathrm{~min}$, after which the reaction was stirred for additional $4 \mathrm{~h}$. The reaction was quenched with $50 \mathrm{~mL}$ saturated $\mathrm{NH}_{4} \mathrm{Cl}$, and the organic solvent was then removed under reduced pressure. The remaining mixture was extracted with $\mathrm{CH}_{2} \mathrm{Cl}_{2}(\mathrm{x} 3)$, and the organic phase was washed with brine and dried with $\mathrm{Na}_{2} \mathrm{SO}_{4}$. The residue was concentrated under vacuum and purified by column liquid chromatography on silica gel with Hexane:EtOAc (85:15). The starting material was recovered with an $\mathrm{rf}$ of 0.7 , and the desired product was eluted with an rf of 0.4 (510 mg, $0.97 \mathrm{mmol}, 67 \%)$. 
${ }^{1} \mathrm{H}$ NMR $\left(400 \mathrm{MHz} \mathrm{CDCl}_{3}\right) \delta(\mathrm{ppm}) 7.17(\mathrm{~d}, J=8.1 \mathrm{~Hz}, 1 \mathrm{H}), 6.44-6.40(\mathrm{~m}, 2 \mathrm{H}), 5.98-5.88(\mathrm{~m}$, 1H), $5.36(\mathrm{dq}, \mathrm{J}=17.3,1.5 \mathrm{~Hz}, 1 \mathrm{H}), 5.25(\mathrm{dq}, \mathrm{J}=10.3,1.2 \mathrm{~Hz}, 1 \mathrm{H}), 4.89(\mathrm{~d}, J=8.4 \mathrm{~Hz}, 1 \mathrm{H}), 4.68-$ $4.56(\mathrm{~m}, 2 \mathrm{H}), 4.32$ (br. s, 1H), 3.85 (d, J = 12.8 Hz, 1H), 3.82 (s, 3H), 3.81 (d, J = 5.6 Hz, 1H), 3.79 (s, $3 \mathrm{H}), 3.35(\mathrm{t}, J=7.4 \mathrm{~Hz}, 1 \mathrm{H}), 2.24-2.10(\mathrm{~m}, 2 \mathrm{H}), 1.43(\mathrm{~s}, 18 \mathrm{H})$

${ }^{13} \mathrm{C}$ NMR (101 MHz, CDCl $) \delta$ (ppm) 172.2, 171.3, 160.5, 158.5, 155.5, 132.1, 131.1, 118.7, 118.1, $104.2,99.0,82.2,79.9,66.0,55.7,55.5,52.8,43.6,34.0,30.3,28.4,28.1$

HRMS (ESI) $m / z$ : calculated for $\mathrm{C}_{26} \mathrm{H}_{40} \mathrm{NO}_{8} \mathrm{~S}^{+}(\mathrm{M}+\mathrm{H})^{+}$526.24691; found: 526.24671

\subsubsection{Boc-Glu(OH, SDMB)-OtBu (S10)}

S9 (2.6 g, $5.02 \mathrm{mmol}, 1$ equiv.) was dissolved in $50 \mathrm{~mL}$ THF. $6.2 \mathrm{~mL}$ of phenylsilane $(50.2 \mathrm{mmol}$, 10 equiv.) and $289 \mathrm{mg}$ of $\mathrm{Pd}\left(\mathrm{PPh}_{3}\right)_{4}(0.25 \mathrm{mmol}, 0.05$ equiv. $)$ were added. The reaction was stirred at $\mathrm{rt}$ for $2 \mathrm{~h}$. The solvent was removed under reduced pressure, and the residue was extracted with $\mathrm{CH}_{2} \mathrm{Cl}_{2}(x 3)$. After removing the solvent, the crude product was purified by column liquid chromatography on silica gel with Hexane:EtOAc (3:1 to 1:1). S10 was eluted with 1:1 hexane:EtOAc supplemented with $2 \% \mathrm{CH}_{3} \mathrm{OH}$ and $0.5 \% \mathrm{AcOH}$. The organic phase was extracted with $\mathrm{H}_{2} \mathrm{O}\left(x_{3}\right)$, dried over $\mathrm{Na}_{2} \mathrm{SO}_{4}$, and concentrated under reduced pressure. The desired product was obtained as a brown solid (1.7 g, $3.5 \mathrm{mmol}, 69 \%)$.

${ }^{1} \mathrm{H}$ NMR $\left(400 \mathrm{MHz}, \mathrm{CDCl}_{3}\right) \delta(\mathrm{ppm}) 7.19(\mathrm{~d}, J=8.2 \mathrm{~Hz}, 1 \mathrm{H}), 6.44-6.40(\mathrm{~m}, 2 \mathrm{H}), 5.06(\mathrm{~d}, J=8.1 \mathrm{~Hz}$, 1H), $4.36(\mathrm{q}, J=4.3 \mathrm{~Hz}, 1 \mathrm{H}), 3.84(\mathrm{~d}, J=12.0 \mathrm{~Hz}, 2 \mathrm{H}), 3.83(\mathrm{~s}, 3 \mathrm{H}), 3.78(\mathrm{~s}, 3 \mathrm{H}), 3.36(\mathrm{t}, J=6.9 \mathrm{~Hz}$, $1 \mathrm{H}), 2.26-2.17(\mathrm{~m}, 1 \mathrm{H}), 2.12-2.04(\mathrm{~m}, 1 \mathrm{H}), 1.43(\mathrm{~s}, 18 \mathrm{H})$

${ }^{13} \mathrm{C}$ NMR (101 MHz, $\left.\mathrm{CDCl}_{3}\right) \delta$ (ppm) 177.0, 171.3, 160.5, 158.5, 155.6, 131.2, 117.9, 104.2, 99.0, $82.4,80.1,55.7,55.5,52.6,43.5,34.1,30.6,28.4,28.1$

HRMS (ESI) $m / z$ : calculated for $\mathrm{C}_{23} \mathrm{H}_{34} \mathrm{NO}_{8} \mathrm{~S}^{-}(\mathrm{M}-\mathrm{H})^{-}$484.20106; found: 484.20108 


\section{General protocols for SPPS}

3.1 Coupling of the first amino acid

The resin was washed with dry $\mathrm{CH}_{2} \mathrm{Cl}_{2}$, and a mixture of Fmoc-Xaa-OH (3 equiv.) and Hünig's base (6 equiv.) in dry $\mathrm{CH}_{2} \mathrm{Cl}_{2}$ was added. The resin was agitated for $2 \mathrm{~h}$ and then washed with DMF (x3) and $\mathrm{CH}_{2} \mathrm{Cl}_{2}(\times 3)$.

\subsection{Fmoc deprotection}

A solution of $20 \%$ piperidine in DMF was added to the resin, and the suspension was agitated for $10 \mathrm{~min}$. The procedure was repeated twice. The resin was then washed with $\mathrm{DMF}(\mathrm{x} 3)$ and $\mathrm{CH}_{2} \mathrm{Cl}_{2}$ (x3).

\subsection{Peptide couplings}

Fmoc-Xaa-OH (3 equiv.) and HATU (2.7 equiv.) were dissolved in DMF, and Hünig's base (6 equiv.) was added. After $1 \mathrm{~min}$, the mixture was added to the amino-functionalized resin that was suspended in a minimal amount of DMF. The mixture was agitated for 60 min and washed with $\operatorname{DMF}(x 3)$ and $\mathrm{CH}_{2} \mathrm{Cl}_{2}(x 3)$. Couplings were monitored by test-cleavage of a small portion of resin and subsequent LCMS analysis.

\subsection{Cleavage and side-chain deprotection from the solid support}

The resin was agitated with the mixture TFA: $\mathrm{H}_{2} \mathrm{O}$ :TIPS:EDT $(87.5: 2.5: 2.5: 7.5)$ for $4 \mathrm{~h}$, and the solution was collected by filtration. The filtrate was concentrated under a stream of nitrogen, and the product was precipitated from cold $\mathrm{Et}_{2} \mathrm{O}$. The white solid was isolated by centrifugation of the suspension and decanting the supernatant. The solid was triturated with $\mathrm{Et}_{2} \mathrm{O}(\mathrm{x} 2)$ and $\mathrm{CH}_{3} \mathrm{CN}(\times 3)$. The residual white solid was dried under a stream of nitrogen, dissolved in $\mathrm{H}_{2} \mathrm{O}$, and lyophilized to obtain the tripeptide as a white solid at a purity of at least 95\% (based on LCMS and $\left.{ }^{1} \mathrm{H} N M R\right)$. 
3.5 lon exchange of the peptides

Peptides ( 100 mg) were reacted with $\mathrm{HCl}(1 \mathrm{M}, \sim 1 \mathrm{~mL})$ for $1 \mathrm{~min}$, and the solvent was removed under reduced pressure. The procedure was repeated at least two more times until no TFA signal was observed by recording ${ }^{19} \mathrm{~F}$ NMR spectra.

\subsection{Thiolactone hydrolysis}

Peptides $\mathbf{2}$ and $\mathbf{3}$ underwent spontaneous thiolactone formation with the backbone carboxylic acid and the thiol group of Z. To hydrolyze the peptides, 1.2 equiv. of $4 \mathrm{M} \mathrm{NaOH}$ were added, and the peptides were mixed for $1 \mathrm{~h}$. LCMS and ${ }^{13} \mathrm{C}$ NMR were used to determine the completion of the hydrolysis, and the peptides were lyophilized.

\section{Analytical data of the peptides}

4.1 $\mathrm{H}_{2} \mathrm{~N}-\gamma$ Glu-Cys-Gly-OH (GSH)<smiles>N[C@@H](CCC(=O)NC(CS)C(=O)NCC(=O)O)C(=O)O</smiles>

${ }^{1} \mathrm{H}$ NMR (400 MHz, D 20$) \delta(p p m) 4.57(t, J=4.9 \mathrm{~Hz}, 1 \mathrm{H}), 3.99(\mathrm{~d}, J=1.0 \mathrm{~Hz}, 2 \mathrm{H}), 3.83(\mathrm{t}, J=5.0 \mathrm{~Hz}$, $1 \mathrm{H}), 2.99-2.91(\mathrm{~m}, 2 \mathrm{H}), 2.62-2.51(\mathrm{~m}, 2 \mathrm{H}), 2.18(\mathrm{q}, J=5.8 \mathrm{~Hz}, 2 \mathrm{H})$

${ }^{13} \mathrm{C}$ NMR (101 MHz, D 20 ) $\delta$ (ppm) 174.8, 173.5, 173.5, 172.4, 55.6, 53.7, 41.4, 31.1, 25.9, 25.3 HRMS (ESI) $m / z$ : calculated for $\mathrm{C}_{10} \mathrm{H}_{18} \mathrm{~N}_{3} \mathrm{O}_{6} \mathrm{~S}^{+}(\mathrm{M}+\mathrm{H})^{+}$308.09108; found: 308.09088 
4.2 $\mathrm{H}_{2} \mathrm{~N}-\gamma$ Glu-SAsp-Gly-OH (1)<smiles>N[C@@H](CCC(=O)N[C@H](C(=O)NCC(=O)O)C(S)C(=O)O)C(=O)O</smiles>

${ }^{1} \mathrm{H}$ NMR $\left(600 \mathrm{MHz}, \mathrm{D}_{2} \mathrm{O}\right) \delta(\mathrm{ppm}) 5.01(\mathrm{~d}, J=6.8 \mathrm{~Hz}, 1 \mathrm{H}), 4.10-4.01(\mathrm{~m}, 4 \mathrm{H}), 2.67-2.55(\mathrm{~m}, 2 \mathrm{H})$, $2.27-2.21(\mathrm{~m}, 2 \mathrm{H})$

${ }^{13} \mathrm{C}$ NMR (101 MHz, D 20$) \delta$ (ppm) 174.4, 174.2, 172.8, 171.7, 171.0, 55.8, 52.3, 41.4, 41.1, 30.9, 25.4

HRMS (ESI) $m / z$ : calculated for $\mathrm{C}_{11} \mathrm{H}_{18} \mathrm{~N}_{3} \mathrm{O}_{8} \mathrm{~S}^{+}(\mathrm{M}+\mathrm{H})^{+} 352.08091$; found: 352.08051

4.3 $\mathrm{H}_{2} \mathrm{~N}-\gamma$ SGlu-Cys-Gly-OH (2)<smiles>N[C@@H](C[C@H](S)C(=O)NC(CS)C(=O)NCC(=O)O)C(=O)O</smiles>

${ }^{1} \mathbf{H}$ NMR (400 MHz, D 20$) \delta(p p m) 4.27(t, J=5.9 \mathrm{~Hz}, 1 \mathrm{H}), 3.76(\mathrm{~d}, J=9.0 \mathrm{~Hz}, 2 \mathrm{H}), 3.66-3.63(\mathrm{~m}$, 1H), 3.57-3.54 (m, 1H), $2.92(\mathrm{~d}, J=5.9 \mathrm{~Hz}, 2 \mathrm{H}), 2.18-2.13(\mathrm{~m}, 1 \mathrm{H}), 2.01-1.97(\mathrm{~m}, 1 \mathrm{H})$

${ }^{13} \mathrm{C}$ NMR (101 MHz, D 20 ) $\delta$ (ppm) 179.2, 179.0, 176.6, 173.8, 62.4, 57.7, 54.4, 43.3, 39.7, 26.9

HRMS (ESI) $m / z$ : calculated for $\mathrm{C}_{10} \mathrm{H}_{16} \mathrm{~N}_{3} \mathrm{O}_{6} \mathrm{~S}_{2}^{-}(\mathrm{M}-\mathrm{H})^{-}$338.04860; found: 338.04859

4.4 $\mathrm{H}_{2} \mathrm{~N}-\gamma \mathrm{SGlu}-\mathrm{SAsp}-\mathrm{Gly}-\mathrm{OH}(3)$<smiles>N[C@@H](C[C@H](S)C(=O)N[C@H](C(=O)NCC(=O)O)C(S)C(=O)O)C(=O)O</smiles>

${ }^{1} \mathrm{H}$ NMR $\left(400 \mathrm{MHz}, \mathrm{D}_{2} \mathrm{O}\right) \delta(\mathrm{ppm}) 4.98(\mathrm{~d}, J=6.2 \mathrm{~Hz}, 1 \mathrm{H}), 4.05(\mathrm{~d}, J=6.1 \mathrm{~Hz}, 1 \mathrm{H}), 4.00(\mathrm{~d}, J=5.6$ $\mathrm{Hz}, 2 \mathrm{H}), 3.89(\mathrm{t}, J=7.1 \mathrm{~Hz}, 1 \mathrm{H}), 3.75(\mathrm{t}, J=7.9 \mathrm{~Hz}, 1 \mathrm{H}), 2.43(\mathrm{q}, J=7.4 \mathrm{~Hz}, 1 \mathrm{H}), 2.30(\mathrm{q}, J=7.0 \mathrm{~Hz}$, 1H)

${ }^{13} \mathrm{C}$ NMR (101 MHz, D 20$) \delta$ (ppm) 175.7, 174.7, 173.7, 173.3, 171.2, 56.6, 52.4, 42.7, 41.6, 37.9, 35.7

HRMS (ESI) $m / z$ : calculated for $\mathrm{C}_{11} \mathrm{H}_{16} \mathrm{~N}_{3} \mathrm{O}_{8} \mathrm{~S}_{2}^{-}(\mathrm{M}-\mathrm{H})^{-}$382.03843; found: 382.03834 


\section{In vitro studies}

\subsection{Recovery / Rescue assay}

HT-29 cells were chosen as a representative human cell-line due to their high Pb sensitivity and as their medium, RPMI-1640, is compatible with $\mathrm{Pb}(\mathrm{II})$, inhibiting metal precipitation.

HT-29 cells were grown in 25 mM HEPES RPMI-1640 medium, supplemented with 1\% Lglutamine, $1 \%$ penicillin/streptomycin and 10\% fetal calf serum (FCS) superior (standardized) at $37{ }^{\circ} \mathrm{C}$ and $5 \% \mathrm{CO}_{2}$. 96-well plates were prepared such that every well contained 10,000 cells in $100 \mu \mathrm{L}$ medium, and the cells were allowed to adhere for $24 \mathrm{~h}$.

To all wells but the positive control wells, $10 \mu \mathrm{L}$ of $22 \mathrm{mM} \mathrm{Pb}\left(\mathrm{NO}_{3}\right)_{2}$ were added (final concentration $2 \mathrm{mM}$ ). $10 \mu \mathrm{L}$ of $\mathrm{H}_{2} \mathrm{O}$ was added to the positive control wells. 60 min after the addition of the metal salt, $10 \mu \mathrm{L}$ of each solution of the examined peptide $(2.4,6,12,24$, and 48 $\mathrm{mM}$ ) were added to reach final concentrations of $0.2,0.5,1,2$, and $4 \mathrm{mM}$ (which are $0.1,0.25$, $0.5,1$, and 2 equivalents, respectively). To the positive control wells containing no metal and the negative control wells containing metal but no peptides, $10 \mu \mathrm{L}$ of $\mathrm{H}_{2} \mathrm{O}$ were added, respectively. Each condition was performed in triplicates.

The plates were incubated at $37{ }^{\circ} \mathrm{C}$, and $5 \% \mathrm{CO}_{2}$ for additional $23 \mathrm{~h}$, after which the medium was removed, the wells were washed with $\mathrm{H}_{2} \mathrm{O}$, and $50 \mu \mathrm{L}$ of crystal violet solution ${ }^{4,5}$ (500 mg crystal violet powder in $20 \mathrm{~mL} \mathrm{CH} 3 \mathrm{OH}$ and $80 \mathrm{~mL} \mathrm{H}_{2} \mathrm{O}$ ) were added to each well. The plates were gently shaken (50 rpm) for 20 min. The plates were then washed with $\mathrm{H}_{2} \mathrm{O}$ until no more unbound dye was observed and allowed to dry overnight. $100 \mu \mathrm{L}$ of $\mathrm{CH}_{3} \mathrm{OH}$ were added to each well, and the plates were gently shaken (50 rpm) for $20 \mathrm{~min}$, after which their absorbance at $560 \mathrm{~nm}$ was recorded. 
The recovery and rescue values of each concentration of a peptide were calculated according to Equation 1 (relative to the negative control) and Equation 2 (relative to the positive control), respectively:

$$
\begin{aligned}
& \text { Recovery } \%=\frac{A\left[\text { Pep }_{X}\right]-A[\text { blank }]}{A[N E G]-A[\text { blank }]} \times 100 \% \\
& \text { Rescue } \%=\frac{A\left[\text { Pep }_{X}\right]-A[\text { blank }]}{A[\text { POS }]-A[\text { blank }]} \times 100 \%
\end{aligned}
$$

$\mathrm{A}[\mathrm{Pep} \mathrm{x}]$ - absorbance of the pre-toxified well in the presence of $\mathrm{X} \mathrm{mM}$ of peptide

A[blank $]$ - absorbance of an empty well

$A[N E G]$ - absorbance of the pre-toxified well that was not treated with any peptide

$A[P O S]$ - absorbance of the non-treated well

Each experiment was performed on three independent repeats. Values are mean \pm SD.

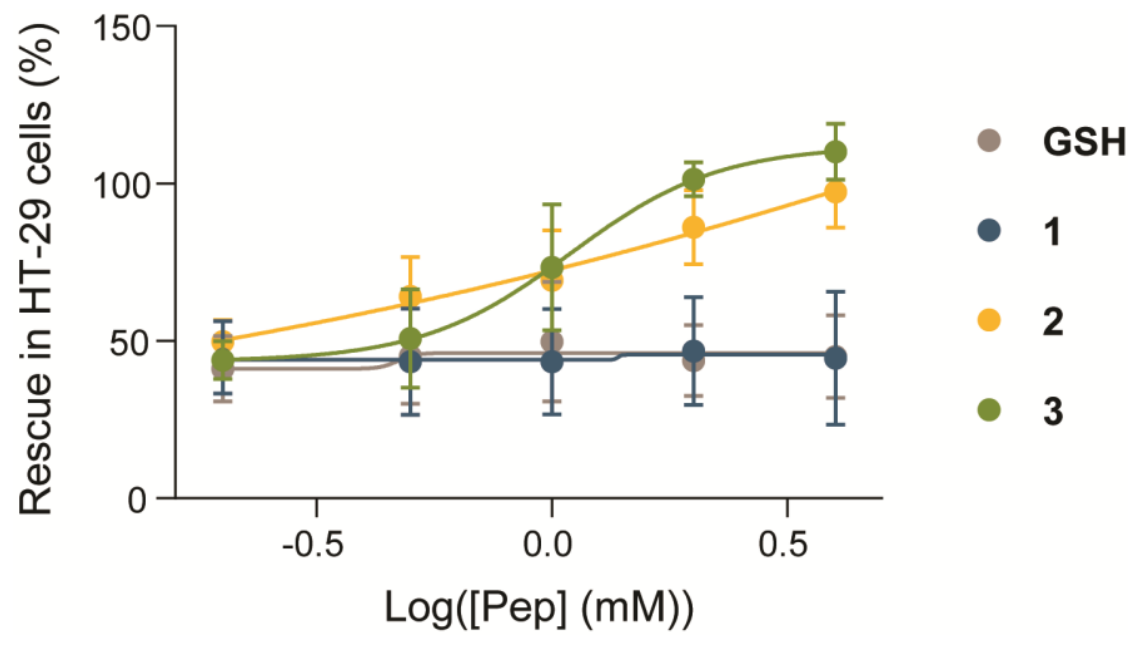

Figure S1. Dose-dependent rescue of HT-29 cells treated with $\mathrm{Pb}\left(\mathrm{NO}_{3}\right)_{2}(2 \mathrm{mM})$ followed by the administration of $\mathrm{GSH}, \mathbf{1}, \mathbf{2}$, and $\mathbf{3}$ (1 $\mathrm{h}$ after the addition of $\mathrm{Pb}(\mathrm{II})$ ions; values are calculated relative to non-treated cells as the positive control). Values are mean \pm SD of at least 3 repeats. 


\subsection{Toxicity assay}

96-well plates were prepared such that every well contained 10,000 HT-29 cells in $100 \mu \mathrm{L}$ medium, and the cells were allowed to adhere for $24 \mathrm{~h}$.

To all wells but the positive control wells, $10 \mu \mathrm{L}$ of each solution of the examined peptides (2.4, $6,12,24$, and $48 \mathrm{mM}$ ) were added to reach final concentrations of $0.2,0.5,1,2$, and $4 \mathrm{mM}$. To the positive control wells, $10 \mu \mathrm{L}$ of $\mathrm{H}_{2} \mathrm{O}$ was added. Each condition was performed in triplicates. The plates were incubated at $37^{\circ} \mathrm{C}$, and $5 \% \mathrm{CO}_{2}$ for $23 \mathrm{~h}$, after which the medium was removed, the wells were washed with $\mathrm{H}_{2} \mathrm{O}$, and $50 \mu \mathrm{L}$ of crystal violet solution ${ }^{4}$ (500 mg crystal violet powder in $20 \mathrm{~mL} \mathrm{CH} 3 \mathrm{OH}_{\text {and }} 80 \mathrm{~mL} \mathrm{H} \mathrm{H}_{2} \mathrm{O}$ ) were added to each well. The plates were gently shaken (50 rpm) for $20 \mathrm{~min}$. The plates were then washed with $\mathrm{H}_{2} \mathrm{O}$ until no more unbound dye was observed and allowed to dry overnight. $100 \mu \mathrm{L}$ of $\mathrm{CH}_{3} \mathrm{OH}$ were added to each well, and the plates were gently shaken (50 rpm) for $20 \mathrm{~min}$, after which their absorbance at $560 \mathrm{~nm}$ was recorded. The toxicity of each concentration of a peptide was calculated according to Equation 3:

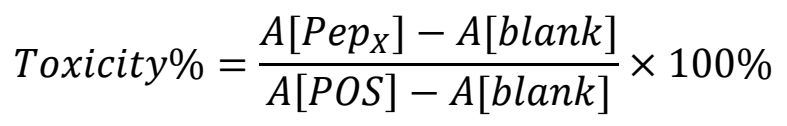

$\mathrm{A}[\mathrm{Pep}] \mathrm{P}-$ absorbance of well in the presence of $\mathrm{X} \mathrm{mM}$ of peptide

A[blank] - absorbance of an empty well

$\mathrm{A}[\mathrm{POS}]-$ absorbance of well that contains no peptides

Each experiment was performed on three independent repeats. Values are mean \pm SD. 


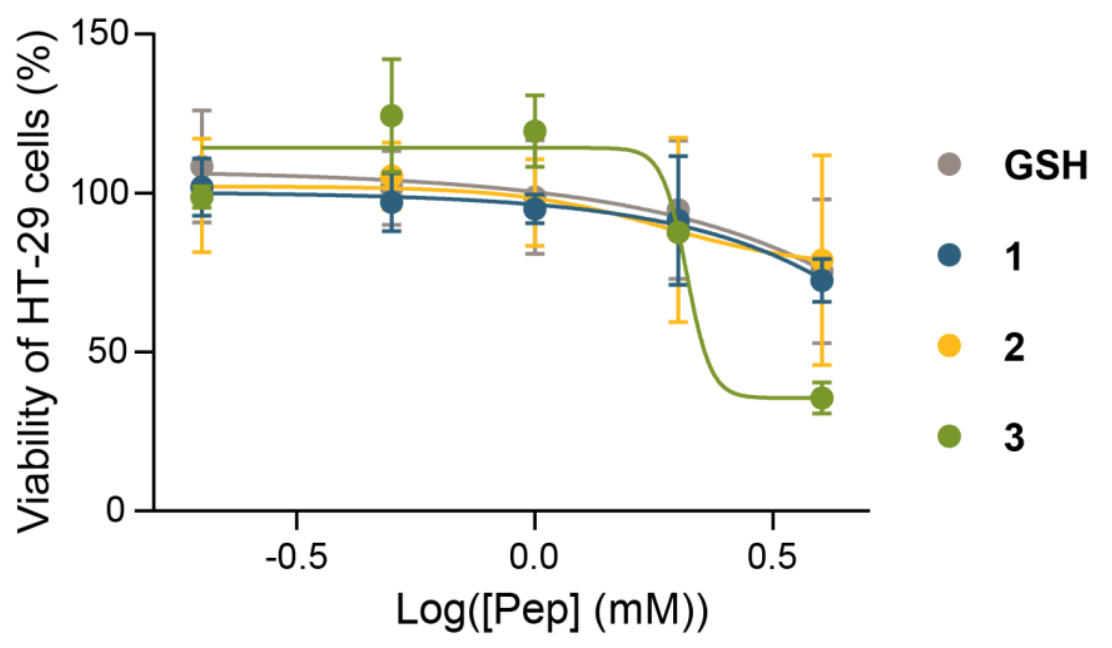

Figure S2. Dose-dependent viability of HT-29 cells treated with GSH, 1, 2, and 3. Values are mean \pm SD of at least 3 repeats.

Table S1. GSH and its three analog peptides investigated herein.

\begin{tabular}{lllll}
\hline Parameter & GSH & $\mathbf{1}$ & $\mathbf{2}$ & $\mathbf{3}$ \\
\hline$C_{50}(\mathrm{mM})$ & n.d. $^{\text {[a] }}$ & n.d. ${ }^{[\mathrm{a}]}$ & n.d. $^{[\mathrm{a}]}$ & $3.1 \pm 0.3$ \\
Max. inhibition $(\%)$ & $25 \pm 12$ & $27 \pm 3$ & $21 \pm 13$ & $65 \pm 1$ \\
\hline
\end{tabular}

[a] Values do not reach $50 \%$ inhibition. 


\subsection{Cellular Pb quantification by ICP-MS}

HT-29 cells were grown in 25 mM HEPES RPMI-1640 medium, supplemented with 1\% Lglutamine, $1 \%$ penicillin/streptomycin and $10 \%$ fetal calf serum (FCS) superior (standardized) at $37{ }^{\circ} \mathrm{C}$ and $5 \% \mathrm{CO}_{2}$. 96-well plates were prepared such that every well contained 10,000 cells in $100 \mu \mathrm{L}$ medium, and the cells were allowed to adhere overnight.

Three different experiments were performed:

Pb poisoning only

To each well, $10 \mu \mathrm{L}$ of $22 \mathrm{mM} \mathrm{Pb}\left(\mathrm{NO}_{3}\right)_{2}$ were added (final concentration $2 \mathrm{mM}$ ). The cells were incubated at $37^{\circ} \mathrm{C}$, and $5 \% \mathrm{CO}_{2}$ for $24 \mathrm{~h} .10 \mu \mathrm{L} \mathrm{H} \mathrm{H}_{2} \mathrm{O}$ were added after $1 \mathrm{~h}$ of incubation.

In vitro protocol

To each well, $10 \mu \mathrm{L}$ of $22 \mathrm{mM} \mathrm{Pb}\left(\mathrm{NO}_{3}\right)_{2}$ were added (final concentration $2 \mathrm{mM}$ ). The cells were incubated at $37^{\circ} \mathrm{C}$ and $5 \% \mathrm{CO}_{2}$ for $1 \mathrm{~h}$. After that, $10 \mu \mathrm{L}$ of $48 \mathrm{mM} 3$ in $\mathrm{H}_{2} \mathrm{O}$ were added, and the cells were further incubated for $23 \mathrm{~h}$.

Reverse in vitro protocol

To each well, $10 \mu \mathrm{L}$ of $48 \mathrm{mM} 3$ were added (final concentration $2 \mathrm{mM}$ ). The cells were incubated at $37^{\circ} \mathrm{C}$ and $5 \% \mathrm{CO}_{2}$ for $1 \mathrm{~h}$. The medium was then removed, and the wells were washed with RPMI $(3 \times 100 \mu \mathrm{L})$. To each well were then added $100 \mu \mathrm{L}$ of fresh RPMI, $10 \mu \mathrm{L} \mathrm{H} \mathrm{H}_{2} \mathrm{O}$ and $10 \mu \mathrm{L}$ of $22 \mathrm{mM} \mathrm{Pb}\left(\mathrm{NO}_{3}\right)_{2}$. The cells were then incubated further for $23 \mathrm{~h}$.

All experiments were performed in triplicates

\section{Sample Preparation}

After $24 \mathrm{~h}$, the medium was removed from the wells, and they were washed with RPMI $3 \times 100$ $\mu \mathrm{L})$. Cells were then digested in the wells by treatment with $100 \mu \mathrm{LNNO}_{3}(70 \%)$ for $1 \mathrm{~h}$ at room temperature. The resulting mixture was homogenized, and $50 \mu \mathrm{L}$ were taken and mixed with further $100 \mu \mathrm{L} \mathrm{HNO}$ (70\%), $42 \mu \mathrm{L}$ of $\mathrm{Lu}_{2} \mathrm{O}_{3}\left(250 \mathrm{mg} / \mathrm{L}\right.$ in $\left.\mathrm{HNO}_{3}\right)$, and $3.808 \mathrm{~mL}$ of $\mathrm{H}_{2} \mathrm{O}$. 
Table S2 Pb content determined by ICP-MS (counts sec ${ }^{-1}$ )

$\mathrm{Pb}\left(\times 10^{6}\right.$ counts $\left.\mathrm{sec}^{-1}\right)$

\begin{tabular}{ll}
\hline Negative control (cells poisoned with $\left.\mathrm{Pb}\left(\mathrm{NO}_{3}\right)_{2}\right)$ & $87.5 \pm 4.8$ \\
$\mathrm{~Pb}-$ poisoned cells treated with $\mathbf{3}$ (no washing) & $30.2 \pm 1.7$ \\
$\mathrm{~Pb}$-poisoned cells treated with 3 (with washing) & $24.7 \pm 3.6$ \\
\hline
\end{tabular}

\section{Complexes characterization}

6.1 Determination of complexation stoichiometries with HR-ESI-MS
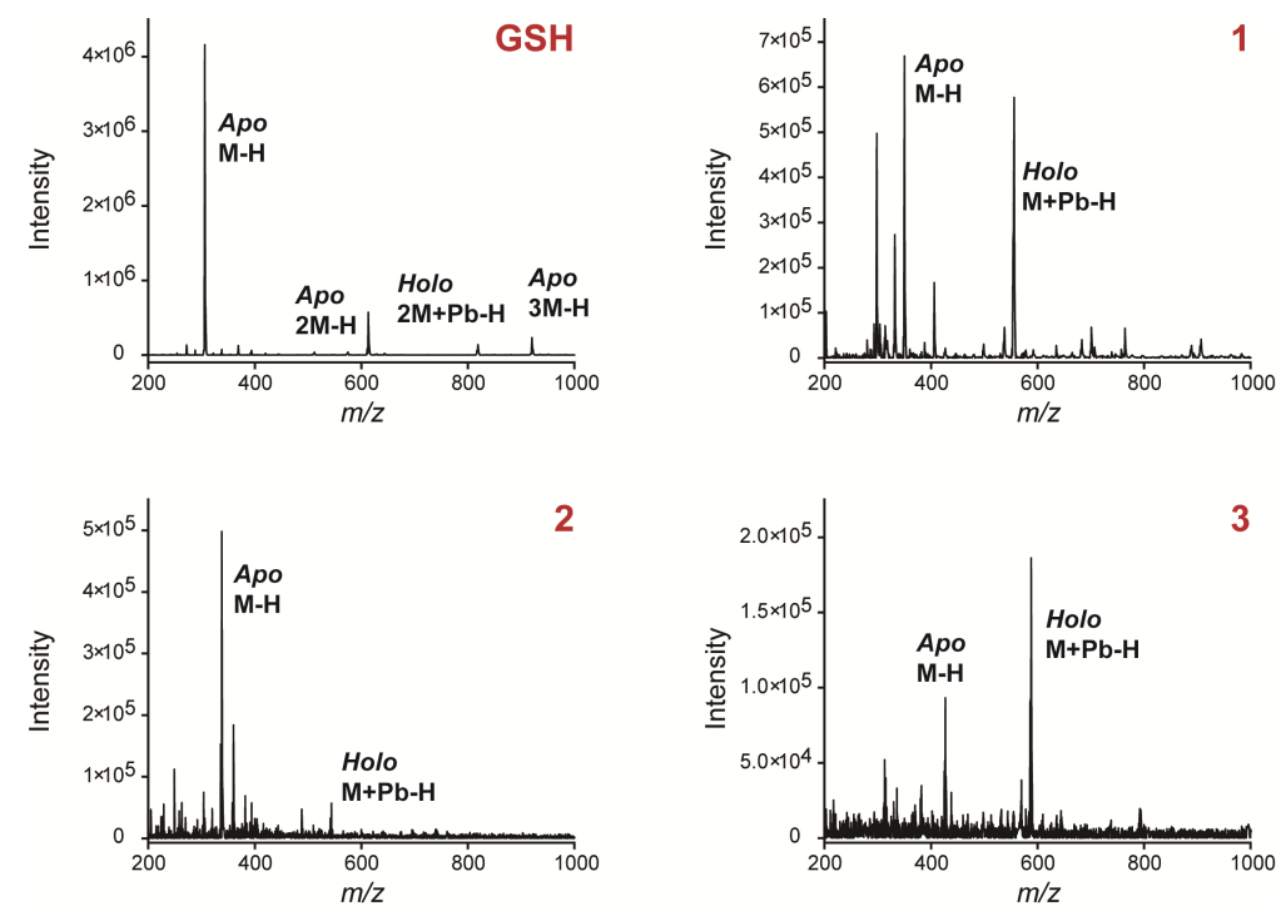

Figure S3. Full negative HR-ESI-MS spectra $(m / z$ 200-1000) of GSH and peptides 1-3 (100 $\mu \mathrm{M})$ incubated with $\mathrm{Pb}\left(\mathrm{NO}_{3}\right)_{2}(100 \mu \mathrm{M})$ in $\mathrm{H}_{2} \mathrm{O}$. 
6.2 Affinity and stoichiometry determination with $\mathrm{Pb}\left(\mathrm{NO}_{3}\right)_{2}$ by ITC

Titrations were performed in $20 \mathrm{mM}$ Tris buffer $\mathrm{pH} 6.5$ at $25^{\circ} \mathrm{C}$, where $\mathrm{Pb}\left(\mathrm{NO}_{3}\right)_{2}$ solution $(280 \mu \mathrm{L})$ was titrated to a peptide solution $(1.8 \mathrm{~mL})$ at concentrations according to Table $\mathrm{S} 3$.

Table S3 Peptides and $\mathrm{Pb}\left(\mathrm{NO}_{3}\right)_{2}$ concentrations for ITC-monitored titrations

\begin{tabular}{lll}
\hline & {$[$ Peptide] $(\mu \mathrm{M})$} & {$\left[\mathrm{Pb}\left(\mathrm{NO}_{3}\right)_{2}\right](\mathrm{mM})$} \\
\hline GSH & 200 & 6.0 \\
$\mathbf{1}$ & 20 & 0.6 \\
$\mathbf{2}$ & 200 & 6.0 \\
3 & 20 & 0.9 \\
\hline
\end{tabular}

\subsection{UV-Vis titration of $\mathrm{Pb}\left(\mathrm{NO}_{3}\right)_{2}$ with peptides}

Attempts to reproduce previously published results of $\mathrm{GSH}-\mathrm{Pb}(\mathrm{II})$ titration, ${ }^{6}$ where the peptide concentration was $100 \mu \mathrm{M}$ revealed a very low LMCT of the complex at a 1:1 ratio. We, therefore, measured the UV spectra of GSH-Pb(II) mixtures (1:1) at four concentrations: $100 \mu \mathrm{M}, 1,5$, and $10 \mathrm{mM}$, revealing that a significant LMCT is detected at $5 \mathrm{mM}$ and above.

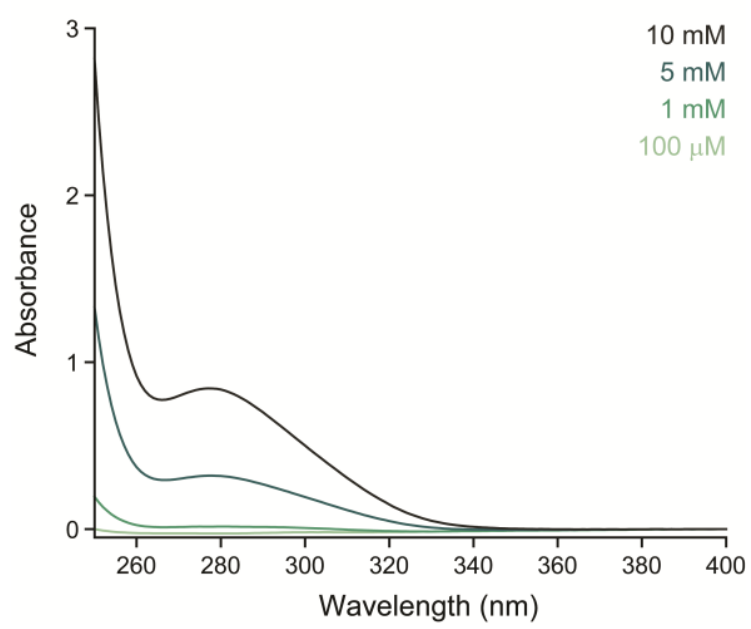

Figure S4. UV titration of $\mathrm{GSH}$ with $\mathrm{Pb}\left(\mathrm{NO}_{3}\right)_{2}$ at an equimolar ratio at four different concentrations. 
To aliquots of peptide $(100 \mu \mathrm{M})$ in $20 \mathrm{mM}$ Tris buffer $\mathrm{pH} 6.5, \mathrm{~Pb}\left(\mathrm{NO}_{3}\right)_{2}$ was added at final concentrations of $25-500 \mu \mathrm{M}$ (equal to $0.25-5$ equivalents), and the total volume was brought to $200 \mu \mathrm{L}$ with Tris buffer. The spectra of each solution were recorded (200-400 nm), and a blank spectrum of only buffer was omitted from all spectra.

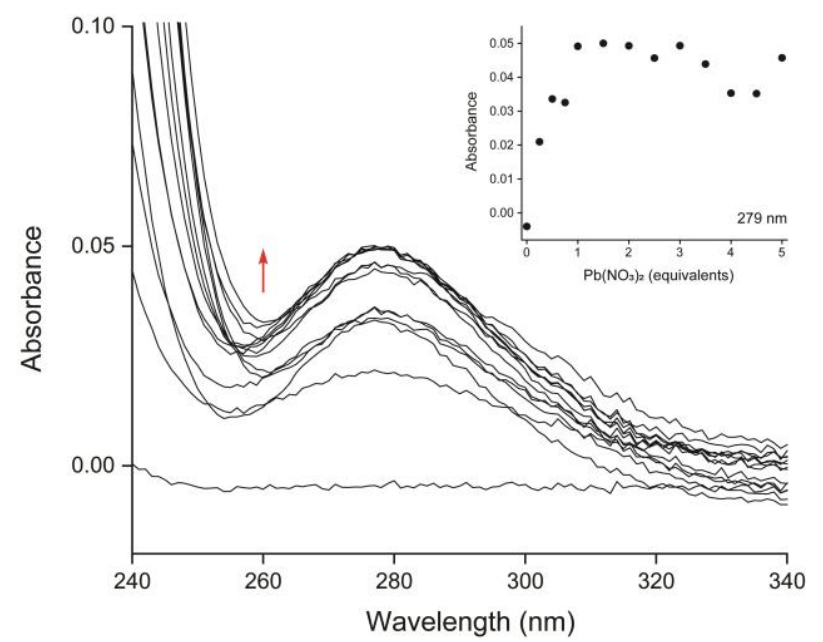

Figure S5. UV titration of $\mathrm{GSH}(100 \mu \mathrm{M})$ with $\mathrm{Pb}\left(\mathrm{NO}_{3}\right)_{2}(0-500 \mu \mathrm{M} ; 0-5$ equiv.) and the absorbance of GSH-titration with $\mathrm{Pb}(\mathrm{II})$ at $279 \mathrm{~nm}$.

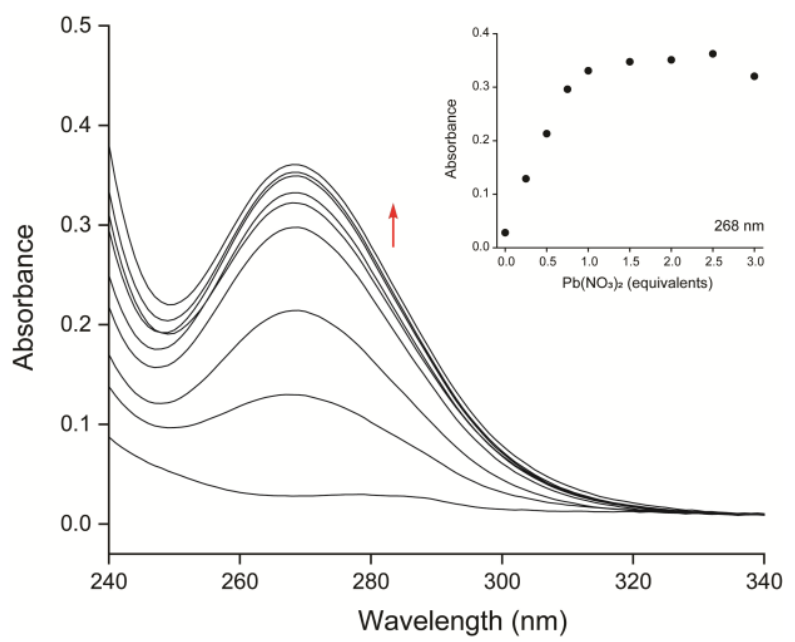

Figure S6. UV titration of $1(100 \mu \mathrm{M})$ with $\mathrm{Pb}\left(\mathrm{NO}_{3}\right)_{2}(0-300 \mu \mathrm{M} ; 0-3$ equiv.) and the absorbance of 1-titration with $\mathrm{Pb}(\mathrm{II})$ at $268 \mathrm{~nm}$. 


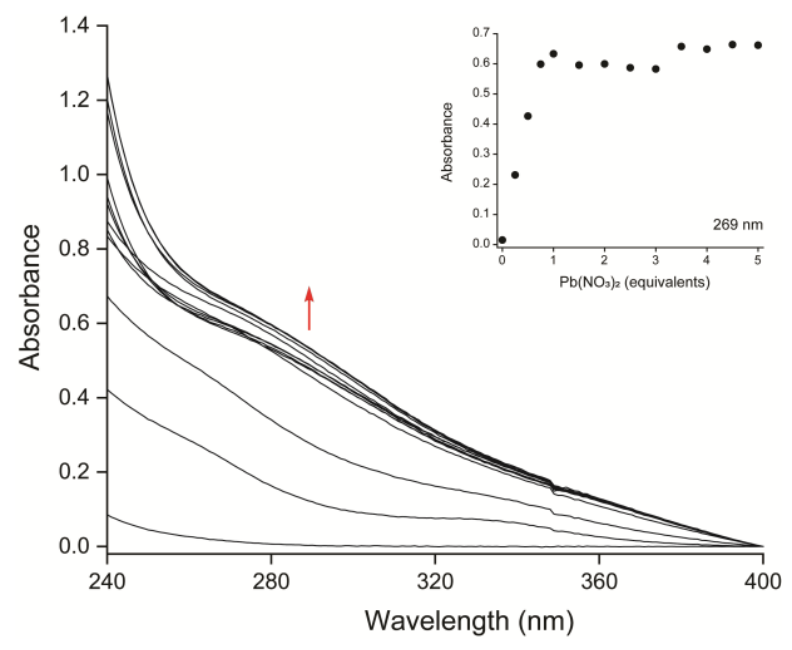

Figure S7. UV titration of $2(100 \mu \mathrm{M})$ with $\mathrm{Pb}\left(\mathrm{NO}_{3}\right)_{2}(0-500 \mu \mathrm{M} ; 0-5$ equiv.) and the absorbance of 2-titration with $\mathrm{Pb}(\mathrm{II})$ at $269 \mathrm{~nm}$.

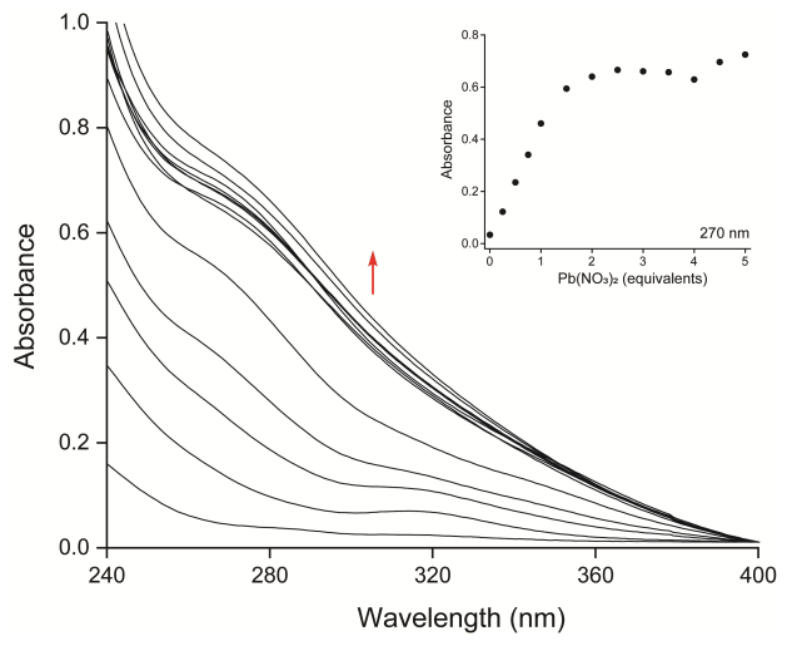

Figure S8. UV titration of $3(100 \mu \mathrm{M})$ with $\mathrm{Pb}\left(\mathrm{NO}_{3}\right)_{2}(0-500 \mu \mathrm{M} ; 0-5$ equiv.) and the absorbance of 3-titration with $\mathrm{Pb}(\mathrm{II})$ at $270 \mathrm{~nm}$. 
6.4 Determination of metal selectivity by UV-Vis titrations

Back-titrations with GSH:

To aliquots of $\mathrm{GSH}$ and $\mathrm{Pb}\left(\mathrm{NO}_{3}\right)_{2}$ at final concentrations of $5 \mathrm{mM}$ in $20 \mathrm{mM}$ Tris buffer $\mathrm{pH} 6.5 \mathrm{ZnCl}_{2}$ $(100 \mathrm{mM})$ or $\mathrm{CaCl}_{2}(1 \mathrm{M})$ were added after $1 \mathrm{~h}$ in 1-10 equivalents for $\mathrm{ZnCl}_{2}$ or 10-100 equivalents for $\mathrm{CaCl}_{2}$, and the total volume was brought to $200 \mu \mathrm{L}$ with Tris buffer. The spectra of each solution were recorded (200-400 nm), and a blank spectrum of only buffer was omitted from all spectra.

Back-titrations with peptides 1, 2, and 3:

To aliquots of peptide and $\mathrm{Pb}\left(\mathrm{NO}_{3}\right)_{2}$ at final concentrations of $100 \mu \mathrm{M}$ in $20 \mathrm{mM}$ Tris buffer $\mathrm{pH}$ $6.5 \mathrm{ZnCl}_{2}(2 \mathrm{mM})$ or $\mathrm{CaCl}_{2}(20 \mathrm{mM})$ were added after $1 \mathrm{~h}$ in 1-10 equivalents for $\mathrm{ZnCl}_{2}$ or $10-100$ equivalents for $\mathrm{CaCl}_{2}$, and the total volume was brought to $200 \mu \mathrm{L}$ with Tris buffer. The spectra of each solution were recorded (200-400 nm), and a blank spectrum of only buffer was omitted from all spectra. 

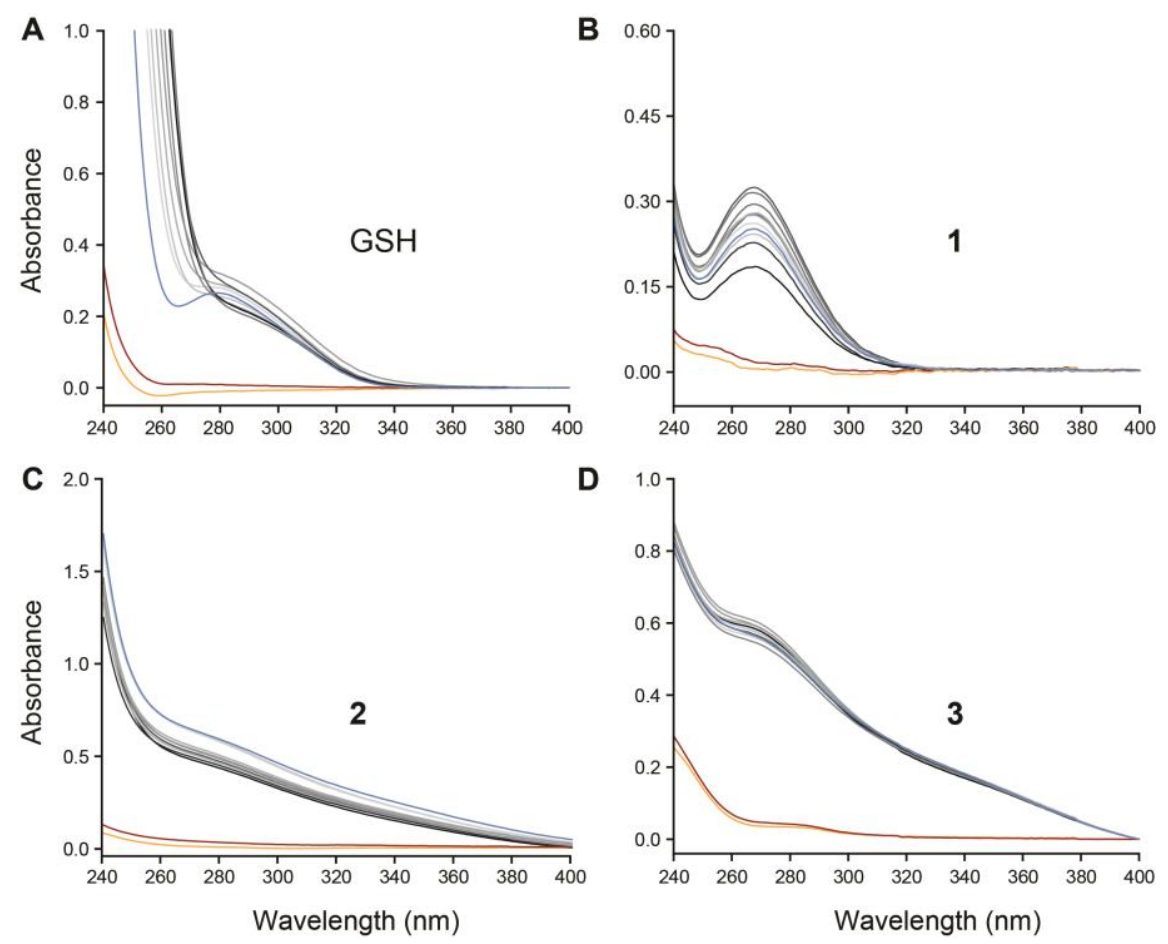

Figure S9. UV-monitored back-titrations of peptides GSH-Pb(II) (5 mM; A), 1-Pb(II) (100 $\mu \mathrm{M}$; B),

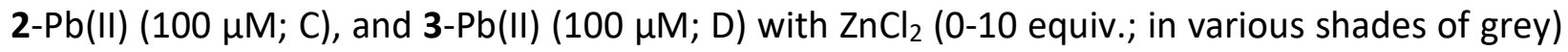
where orange spectra are for apo peptides, red spectra are for peptides with only $\mathrm{ZnCl}_{2}$ (10 equiv.) and blue spectra are for peptides with only $\mathrm{Pb}\left(\mathrm{NO}_{3}\right)_{2}$ (1 equiv.). 

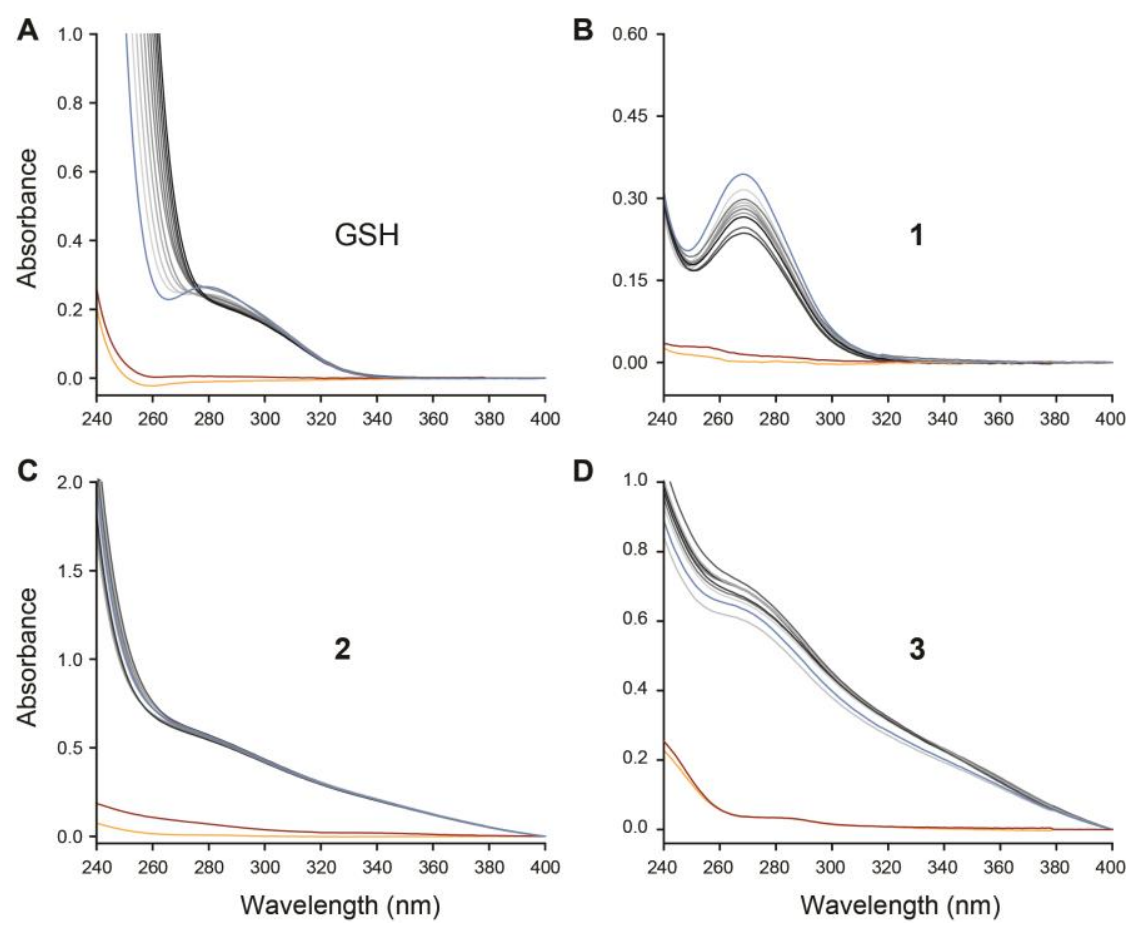

Figure S10. UV-monitored back-titrations of peptides GSH-Pb(II) (5 mM; A), 1-Pb(II) (100 $\mu \mathrm{M} ; \mathrm{B})$,

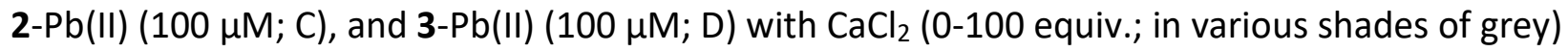
where orange spectra are for apo peptides, red spectra are for peptides with only $\mathrm{CaCl}_{2}(100$ equiv.) and blue spectra are for peptides with only $\mathrm{Pb}\left(\mathrm{NO}_{3}\right)_{2}$ (1 equiv.).

Reversed back-titrations with GSH:

To aliquots of $\mathrm{GSH}(2 \mathrm{mM})$ and $\mathrm{ZnCl}_{2}(20 \mathrm{mM})$ or $\mathrm{CaCl}_{2}(20 \mathrm{mM})$ in $20 \mathrm{mM}$ Tris buffer pH 6.5 $\mathrm{Pb}\left(\mathrm{NO}_{3}\right)_{2}$ was added after $1 \mathrm{~h}$ in 0-1 equivalents compared to the peptide's concentration, and the total volume was brought to $200 \mu \mathrm{L}$ with Tris buffer. The spectra of each solution were recorded (200-400 $\mathrm{nm}$ ), and a blank spectrum of only buffer was omitted from all spectra.

Reversed back-titrations with peptides 1, 2, and 3:

To aliquots of peptide $(100 \mu \mathrm{M})$ and $\mathrm{ZnCl}_{2}(1 \mathrm{mM})$ or $\mathrm{CaCl}_{2}(10 \mathrm{mM})$ in $20 \mathrm{mM}$ Tris buffer pH 6.5 $\mathrm{Pb}\left(\mathrm{NO}_{3}\right)_{2}$ was added after $1 \mathrm{~h}$ in 0-1 equivalents compared to the peptide's concentration, and the total volume was brought to $200 \mu \mathrm{L}$ with Tris buffer. The spectra of each solution were recorded (200-400 $\mathrm{nm})$, and a blank spectrum of only buffer was omitted from all spectra. 

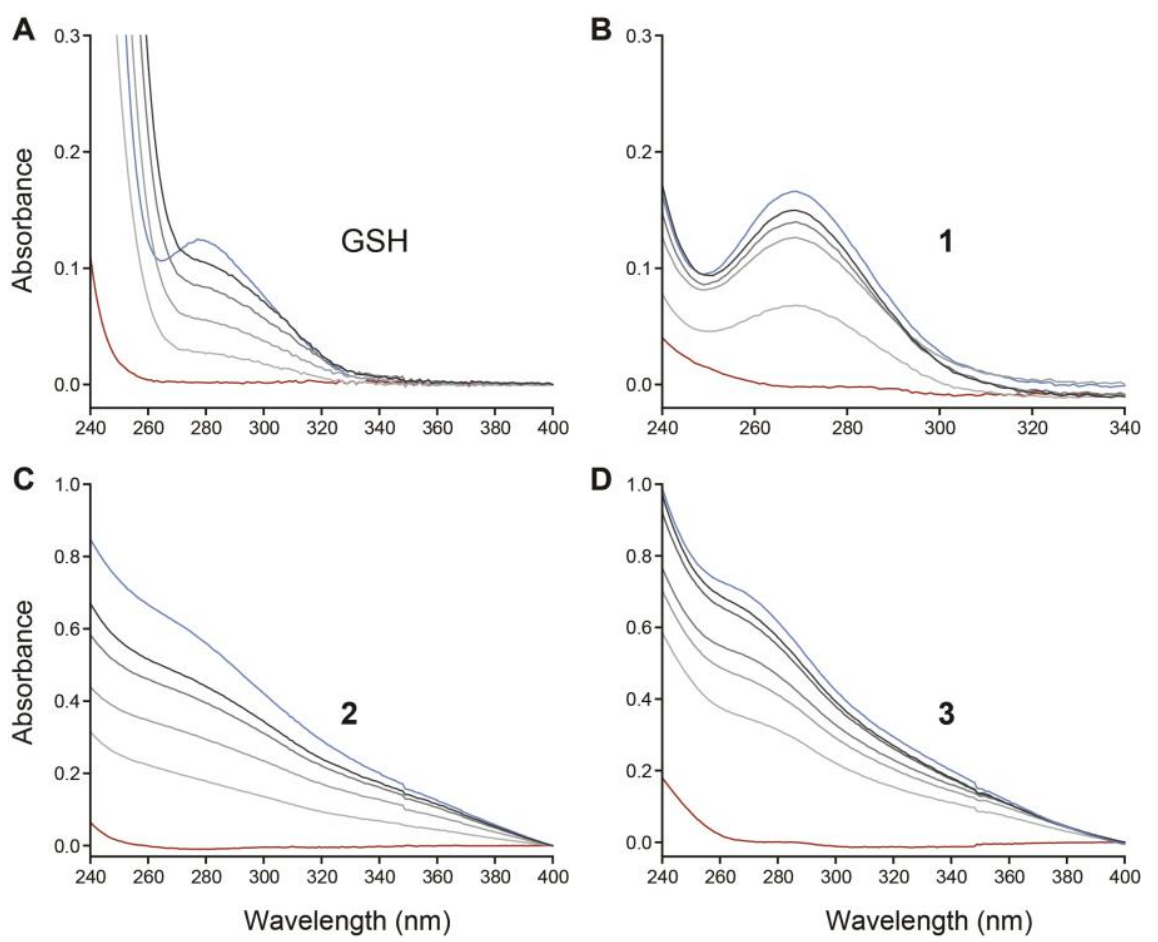

Figure S11. UV-monitored reversed back-titrations of peptides $\mathrm{ZnCl}_{2}$ mixtures $\mathrm{GSH}$ (GSH $2 \mathrm{mM}$;

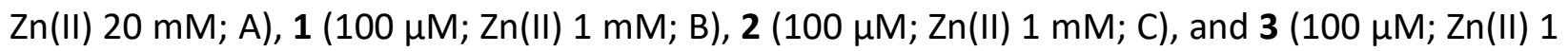
$\mathrm{mM}$; $\mathrm{D}$ ) with $\mathrm{Pb}\left(\mathrm{NO}_{3}\right)_{2}$ (0-1 equiv.; in various shades of grey) where red spectra are for peptides with only $\mathrm{ZnCl}_{2}$ (10 equiv.) and blue spectra are for peptides with only $\mathrm{Pb}\left(\mathrm{NO}_{3}\right)_{2}$ (1 equiv.). 

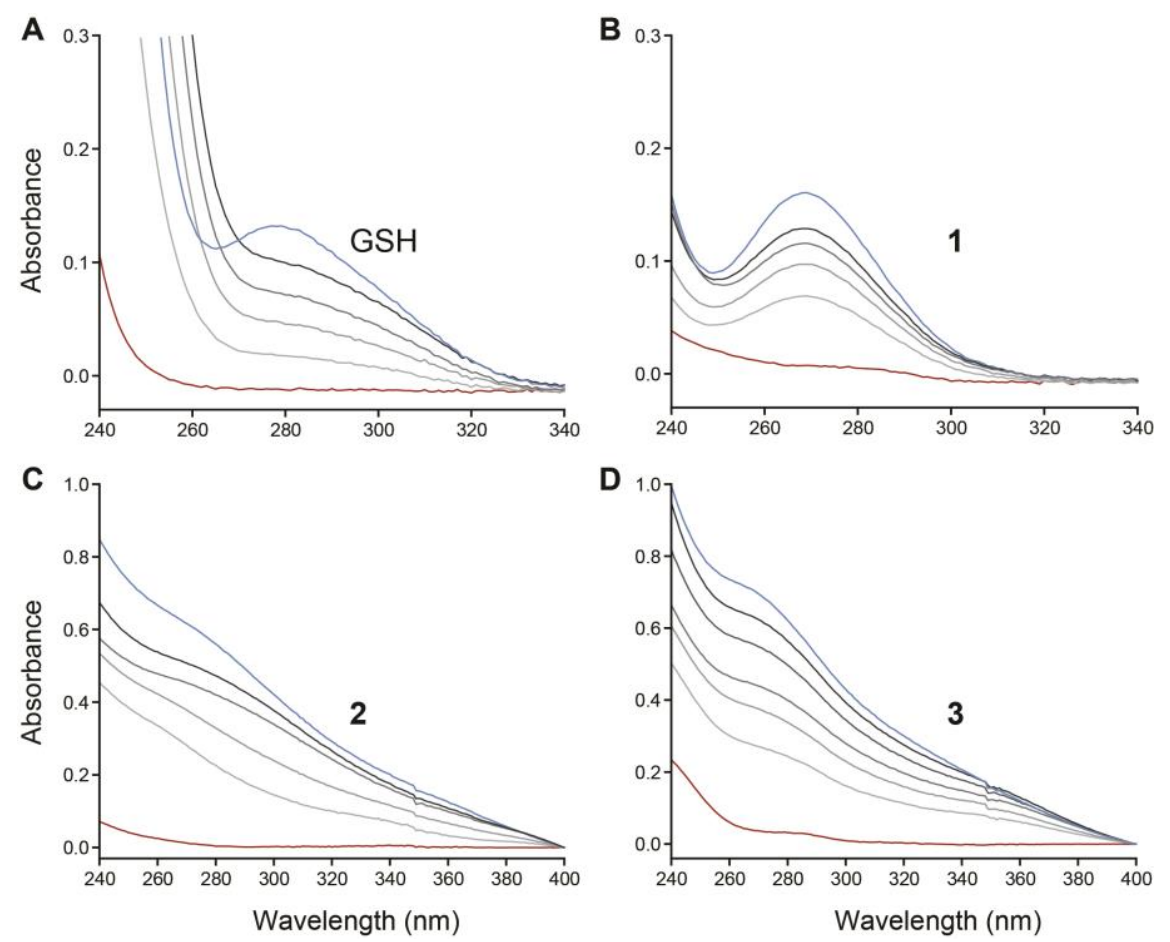

Figure S12. UV-monitored reversed back-titrations of peptides $\mathrm{CaCl}_{2}$ mixtures GSH (GSH 2 mM;

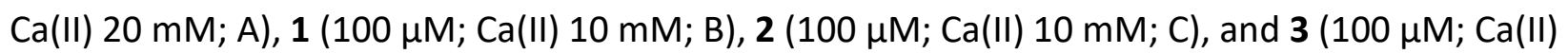
$10 \mathrm{mM}$; D) with $\mathrm{Pb}\left(\mathrm{NO}_{3}\right)_{2}$ (0-1 equiv.; in various shades of grey) where red spectra are for peptides with only $\mathrm{CaCl}_{2}$ (10 or 100 equiv. compared to GSH or 1-3, respectively) and blue spectra are for peptides with only $\mathrm{Pb}\left(\mathrm{NO}_{3}\right)_{2}$ (1 equiv.). 


\section{Quantum chemical calculations}

\subsection{Computational details}

All DFT calculations were carried out using the Turbomole 7.5.1 program. ${ }^{7}$ Geometries of all structures were optimized employing the dispersion-corrected BP86 functional [BP86-D3(BJ) $]^{8-11}$ and the def2-TZVP ${ }^{12}$ basis set (for $\mathrm{Pb}$, this basis set includes the Stuttgart-Dresden effective core potentials) in an implicit solvent with the dielectric constant of $\varepsilon_{r}=80$ corresponding to water - employing the COSMO solvation model ${ }^{13}$ as implemented in Turbomole 7.5.1 program. Subsequent vibrational frequency calculations were performed at the same level of theory for all calculated structures in vacuo after reoptimization (in vacuo). All equilibrium structures possessed zero negative Hessian eigenvalues, so all stationary points were confirmed to be genuine minima on the potential energy surface (PES).

The free energy value corresponding to a particular structure/molecule can be conveniently expressed as (Equation 4):

$$
G_{S}=E_{e l}+\Delta G_{\text {solv }}+E_{Z P V E}-R T \ln \left(q_{\text {trans }} q_{\text {rot }} q_{v i b}\right)+p V
$$

where $E_{\mathrm{el}}$ is the electrostatic potential energy of the molecule in vacuo (gas-phase molecular energy), calculated with a slightly larger basis set, def2-TZVPD and the same functional BP86$\mathrm{D} 3(\mathrm{BJ}), \Delta G_{\text {solv }}$ is the solvation energy calculated by employing the COSMO-RS method (vide infra), $E_{\text {ZPVE }}$ is the zero-point vibrational energy whereas $R T \ln \left(q_{\text {trans }} q_{\text {rot }} q_{\text {vib }}\right)$ are the entropic terms obtained from the rigid-rotor/harmonic oscillator (RRHO) approximation in which a free rotor model was applied for low-lying vibrational modes under $100 \mathrm{~cm}^{-1}$ with a smoothing function applied (sometimes denoted as quasi-RRHO, or RRFRHO approximation). The $E_{\mathrm{el}}$ and $\left(E_{\text {ZPVE }}-R \ln \left(q_{\text {trans }} q_{\text {rot }} q_{\text {vib }}\right)+p V\right)$ are calculated for the in vacuo equilibrium structures. For all structures, we checked that the in vacuo minima do not significantly deviate from their solvent counterparts.

The $\Delta G_{\text {solv }}$ was obtained using Klamt's conductor-like screening model for the realistic solvation method (COSMO-RS). ${ }^{14}$ COSMO-RS calculations were carried out using cosmotherm21 software with the parameter file "BP_TZVPD_FINE_C30_2101.ctd" and the recommended protocol: BP86$\mathrm{D} 3(\mathrm{BJ}) /$ def2-TZVPD single point calculations in vacuo (on top of the in vacuo geometries) and in an ideal conductor $(\varepsilon=\infty)$ for the solvent geometry, followed by the COSMO-RS (cosmotherm21) 
calculations in the target solvent (water). Throughout, FINE cavities (\$cosmo_isorad keyword) were used to increase numerical precision. Finally, a correction of $(1.9 \cdot \Delta n) \mathrm{kcal} \mathrm{mol}^{-1}$ (corresponding to the difference between the concentration of the ideal gas at $298 \mathrm{~K}$ and $1 \mathrm{~atm}$ and its $1 \mathrm{~mol} \mathrm{~L}^{-1}$ concentration; $\Delta n$ is the change in the number of moles in the reaction) has been applied in order that the computed values refer to $1 \mathrm{~mol} \mathrm{~L}^{-1}$ standard state.

\subsection{Definition of a complexation energy}

The following definition of the complexation Gibbs free energy, $\Delta G_{\text {complexation }}$ (which relates to $K_{d}$ as $\Delta G_{\text {complexation }}=R \ln \left(K_{d}\right)$, has been used throughout (Equation 5):

$$
\Delta G_{\text {complexation }}=G_{S}(\text { products })-G_{S}(\text { reactants })
$$

The "reaction" used is the following (Equation 6):

$$
\left[M\left(H_{2} O\right)_{n}\right]^{2+}+(\text { peptide }(S H)) \rightarrow\left[M\left(\text { peptide }\left(S^{-}\right)\left(H_{2} O\right)_{4}\right]^{c+}+(n-x) H_{2} O+z H^{+}\right.
$$

where $n$ is the optimal hydration number -6 for $\mathrm{Zn}(\mathrm{II}), 8$ for $\mathrm{Ca}(\mathrm{II})$, and 5 for $\mathrm{Pb}(\mathrm{II})$ (the lone pair on $\mathrm{Pb}(\mathrm{II})$ leads to (the so-called) hemidirected hydration and the $n=5$ to be the optimal coordination number); $z$ denotes ten number of released protons (Table S4); $x$ denotes the number of water molecules that remain bound to the metal in the complex, which is 4 for all metal ions - $\mathrm{Pb}(\mathrm{II}), \mathrm{Ca}(\mathrm{II})$, and $\mathrm{Zn}(\mathrm{II})$.

This approach was previously tested ${ }^{1}$ with a similar approach involving the calculation of structures with deprotonated thiol groups. Both led to similar results, which proves the robustness of the used computational protocol.

The global minima of the free peptides in a solvent were obtained using Maestro/MD-LLMOD program (Schrodinger, Inc.) with default settings. The MD-LLMOD yielded $\sim 300$ conformers for each of the four peptides that were further processed by the above described QM protocol used throughout this study to find the global minimum. 
Table S4 The number of protons released according to Equation 6.

\begin{tabular}{ll}
\hline Structure & $\mathrm{Z}$ \\
\hline $\mathrm{GSH}-\mathrm{Pb}$ (II) & 1 \\
1-Pb(II) & 1 \\
2-Pb(II) & 2 \\
3-Pb(II) & 1 \\
$\mathrm{GSH}-\mathrm{Zn}(\mathrm{II})$ & 1 \\
1-Zn(II) & 1 \\
2-Zn(II) & 2 \\
3-Zn(II) & 2 \\
$\mathrm{GSH}-\mathrm{Ca}(\mathrm{II})$ & 1 \\
1-Ca(II) & 1 \\
2-Ca(II) & 2 \\
3-Ca(II) & 2 \\
\hline
\end{tabular}

A

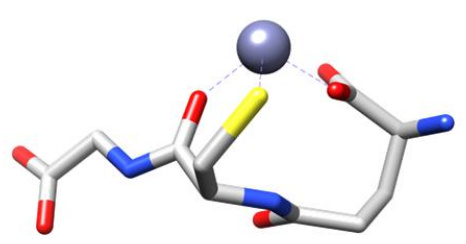

C

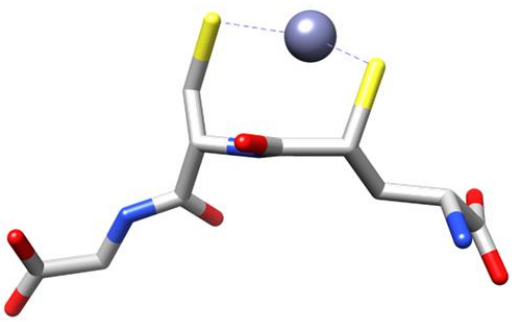

B

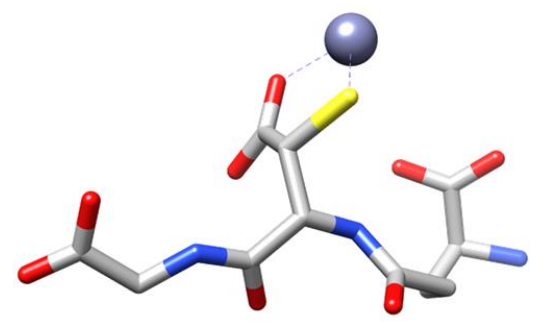

D

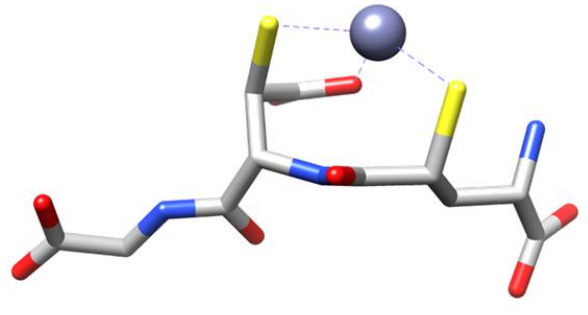

Figure S13. Calculated lowest-energy structures of $\left[\mathrm{Zn} \text { (peptide) } \cdot\left\{\mathrm{H}_{2} \mathrm{O}\right\}_{4}\right]^{\mathrm{C}}(\mathrm{C}=0,-1$ or -2$)$ with $\mathrm{GSH}$ (A), 1 (B), 2 (C), and 3 (D). Hydrogen atoms and four coordinated (or second-sphere) water molecules were omitted for clarity. 


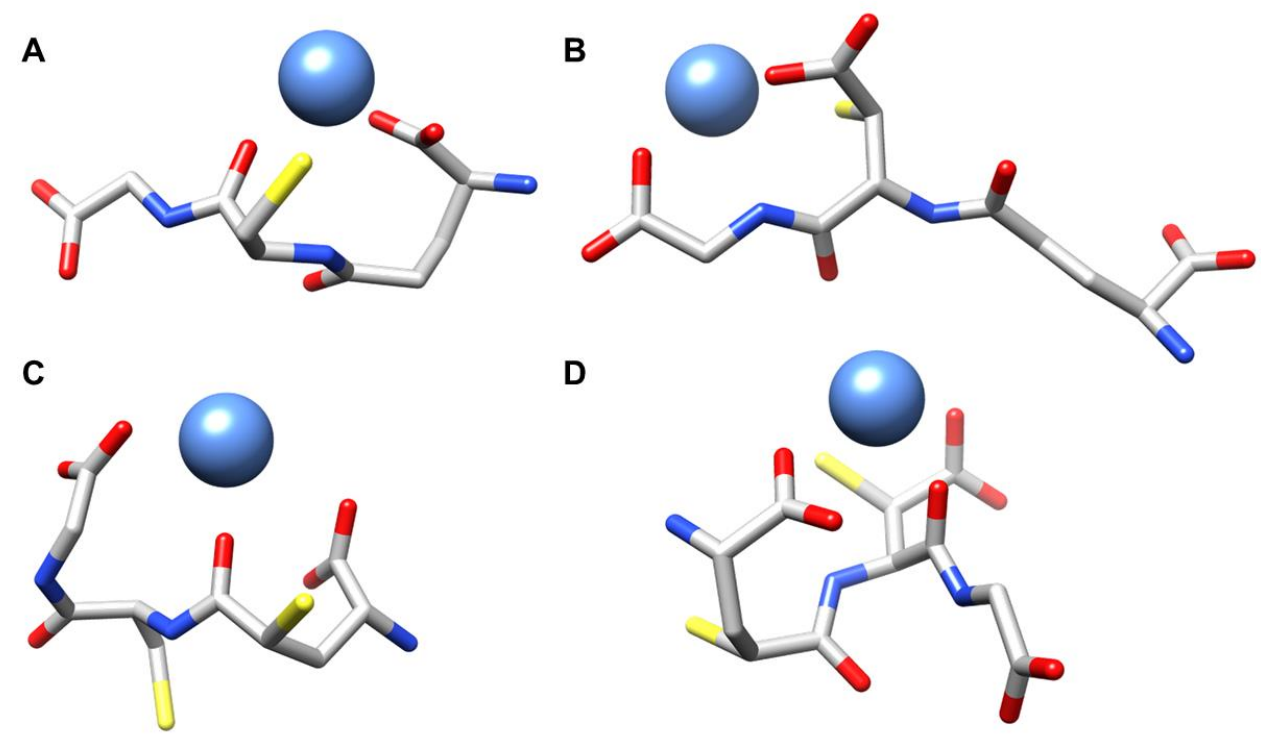

Figure S14. Calculated lowest-energy structures of $\left[\mathrm{Ca} \text { (peptide) } \cdot\left\{\mathrm{H}_{2} \mathrm{O}\right\}_{4}\right]^{\mathrm{C}}(\mathrm{C}=0,-1$ or -2$)$ with GSH (A), 1 (B), 2 (C), and 3 (D). Hydrogen atoms and four coordinated (or second-sphere) water molecules were omitted for clarity. 


\section{References}

(1) Mohammed, T. A.; Meier, C. M.; Kalvoda, T.; Kalt, M.; Rulíšek, L.; Shoshan, M. S. Potent Cyclic Tetrapeptide for Lead Detoxification. Angew. Chem. Int. Ed. 2021, 60, 1238112385.

(2) Thompson, R. E.; Chan, B.; Radom, L.; Jolliffe, K. A.; Payne, R. J. Chemoselective Peptide Ligation-Desulfurization at Aspartate. Angew. Chem. Int. Ed. 2013, 52, 9723-9727.

(3) Cergol, K. M.; Thompson, R. E.; Malins, L. R.; Turner, P.; Payne, R. J. One-Pot Peptide Ligation-Desulfurization at Glutamate. Org. Lett. 2014, 16, 290-293.

(4) Feoktistova, M.; Geserick, P.; Leverkus, M. Crystal Violet Assay for Determining Viability of Cultured Cells. Cold Spring Harb. Protoc. 2016, 2016, 343-346.

(5) Viability assays that are based on reduction, such as MTT, are not suited due to the ability of thiols to reduce the probes.

(6) Jacquart, A.; Brayner, R.; El Hage Chahine, J. M.; Ha-Duong, N. T. Cd(II) and Pb(II) Complexation by Glutathione and the Phytochelatins. Chem. Biol. Interact. 2017, 267, 210.

(7) Balasubramani, S. G.; Chen, G. P.; Coriani, S.; Diedenhofen, M.; Frank, M. S.; Franzke, Y. J.; Furche, F.; Grotjahn, R.; Harding, M. E.; Hättig, C.; Hellweg, A.; Helmich-Paris, B.; Holzer, C.; Huniar, U.; Kaupp, M.; Marefat Khah, A.; Karbalaei Khani, S.; Müller, T.; Mack, F.; Nguyen, B. D.; Parker, S. M.; Perlt, E.; Rappoport, D.; Reiter, K.; Roy, S.; Rückert, M.; Schmitz, G.; Sierka, M.; Tapavicza, E.; Tew, D. P.; Van Wüllen, C.; Voora, V. K.; Weigend, F.; Wodyński, A.; Yu, J. M. TURBOMOLE: Modular Program Suite for Ab Initio QuantumChemical and Condensed-Matter Simulations. J. Chem. Phys. 2020, 152.

(8) A. D. Becke. The Limiting High Temperature Rotational Partition Function of Nonrigid Molecules: I. General Theory. II. $\mathrm{CH}_{4}, \mathrm{C}_{2} \mathrm{H}_{6}, \mathrm{C}_{3} \mathrm{H}_{8}, \mathrm{CH}\left(\mathrm{CH}_{3}\right)_{3}, \mathrm{C}\left(\mathrm{CH}_{3}\right)_{4}$ and $\mathrm{CH}_{3}\left(\mathrm{CH}_{2}\right)_{2} \mathrm{CH}$ 3. III. Benzene and Its Eleven Methyl Derivatives. Phys. Rev. A 1988, 38, 3098.

(9) Vosko, S. H.; Wilk, L.; Nusair, M. Accurate Spin-Dependent Electron Liquid Correlation Energies for Local Spin Density Calculations: A Critical Analysis. Can. J. Phys. 1980, 58, 1200-1211.

(10) Perdew, J. P. Phys. Rev. A. 1986, 33, 8822-8824. 
(11) Grimme, S. Supramolecular Binding Thermodynamics by Dispersion-Corrected Density Functional Theory. Chem. Eur. J. 2012, 18, 9955-9964.

(12) Weigend, F.; Ahlrichs, R. Balanced Basis Sets of Split Valence, Triple Zeta Valence and Quadruple Zeta Valence Quality for H to Rn: Design and Assessment of Accuracy. Phys. Chem. Chem. Phys. 2005, 7, 3297-3305.

(13) Klamt, A.; Schüürmann, G. COSMO: A New Approach to Dielectric Screening in Solvents with Explicit Expressions for the Screening Energy and Its Gradient. J. Chem. Soc. Perkin Trans. 2 1993, 5, 799-805.

(14) Klamt, A. Conductor-like Screening Model for Real Solvents: A New Approach to the Quantitative Calculation of Solvation Phenomena. J. Phys. Chem. 1995, 99, 2224-2235. 